\title{
Targeted Overexpression of IGF-I Evokes Distinct Patterns of Organ Remodeling in Smooth Muscle Cell Tissue Beds of Transgenic Mice
}

\author{
Jianwei Wang, ${ }^{*}$ Wen Niu, ${ }^{\star}$ Yuri Nikiforov, ${ }^{\star}$ Shinji Naito, ${ }^{*}$ Steven Chernausek, ${ }^{\ddagger}$ David Witte, ${ }^{\S}$ Derek LeRoith, \\ Arthur Strauch," and James A. Fagin* \\ *Division of Endocrinology and Metabolism, ${ }^{\ddagger}$ Division of Pediatric Endocrinology, ${ }^{\S}$ Division of Pediatric Pathology, University of \\ Cincinnati, Cincinnati, Ohio 45267; "Diabetes Branch, National Institutes of Diabetes and Digestive and Kidney Diseases, National \\ Institutes of Health, Bethesda, Maryland 20892; and " ${ }^{\dddot{T}}$ Department of Cell Biology, Neurobiology and Anatomy, Ohio State University, \\ Columbus, Ohio 43210
}

\begin{abstract}
Smooth muscle cells (SMC) of the vascular wall, bladder, myometrium, and gastrointestinal and respiratory tracts retain the ability to proliferate postnatally, which enables adaptive responses to injury, hormonal, or mechanical stimulation. SMC growth is regulated by a number of mesenchymal growth factors, including insulin-like growth factor I (IGF-I). To explore the function of IGF-I on SMC in vivo, the mouse SMC $\alpha$-actin promoter fragment SMP8 $(-1074$ $\mathrm{bp}, 63 \mathrm{bp}$ of $5^{\prime} \mathrm{UT}$ and $2.5 \mathrm{~kb}$ of intron 1) was cloned upstream of rat IGF-I cDNA, and the fusion gene microinjected to fertilized eggs of the FVB-N mouse strain. Mating of hemizygous mice with controls produced about 50\% transgenic offspring, with equal sex distribution. Transgenic IGF-I mRNA expression was confined to SMC-containing tissues, with the following hierarchy: bladder $>$ stomach $>$ aorta $=$ uterus $>$ intestine. There was no transgene expression in skeletal muscle, heart, or liver. Radioimmunoassayable IGF-I content was increased by 3.5- to 4-fold in aorta, and by almost 10 -fold in bladder of transgenic mice at 5 and $10 \mathrm{wk}$, with no change in plasma IGF-I levels. Wet weight of bladder, stomach, intestine, uterus, and aorta was selectively increased, with no change in total body or carcass weight of transgenic animals. In situ hybridization showed that transgene expression was exquisitely targeted to the smooth muscle layers of the arteries, veins, bladder, ureter, stomach, intestine, and uterus. Paracrine overproduction of IGF-I resulted in hyperplasia of the muscular layers of these tissues, manifesting in remarkably different phenotypes in the various SMC beds. Whereas the muscular layer of the bladder and stomach exhibited a concentric thickening, the SMC of the intestine and uterus grew in a longitudinal fashion, resulting in a marked lengthening of the small bowel and of the uterine horns. This report describes the first successful targeting of expression of any functional protein capable of modifying the phenotype of SMC in transgenic mice. IGF-I stimulates SMC hyperplasia, leading to distinct patterns of organ remodeling in the different
\end{abstract}

Address correspondence to James A. Fagin, M.D., Division of Endocrinology and Metabolism, University of Cincinnati College of Medicine, 231 Bethesda Ave., Room 5564, Cincinnati, OH 45267-0547. Phone: 513-558-4444; FAX: 513-558-8581; E-mail: faginja@uc.edu

Received for publication 24 March 1997 and accepted in revised form 30 June 1997.

The Journal of Clinical Investigation

Volume 100, Number 6, September 1997, 1425-1439

http://www.jci.org tissue environments. (J. Clin. Invest. 1997. 100:1425-1439.) Key words: alpha actin $•$ IGF binding proteins $\bullet$ hyperplasia . small intestine $\bullet$ bladder

\section{Introduction}

Smooth muscle cells (SMC) ${ }^{1}$ provide structure, elasticity, and contractile properties to a number of tissue compartments, including the peripheral blood vessels. SMC of the vascular wall, urinary bladder, myometrium, and gastrointestinal and respiratory tracts retain the capability to proliferate postnatally, which enables a number of adaptive responses to injury, hormonal or mechanical stimulation. Growth of SMC is subject to regulation by a number of mesenchymal growth factors, including insulin-like growth factor I (IGF-I).

IGF-I, a small polypeptide with structural homology to IGF-II and proinsulin, is produced by many cell types and acts as an autocrine/paracrine growth factor. It also functions as a circulating hormone, as it is present at high concentrations in plasma, where it is associated with specific binding proteins (IGFBP). The relative contribution of locally produced and circulating IGF-I to the biological activity of the growth factor remains unclear. This is complicated by the fact that each tissue environment has a specific set of IGFBPs and IGFBP-specific proteases that modulate the bioavailability of IGF-I and its access to its specific cognate membrane receptor. There is ample evidence that IGF-I stimulates SMC growth in vitro (1, 2). Information on the possible action of IGF-I in SMC tissue beds in vivo, however, is conjectural, and based primarily on descriptions of the regulation of IGF-I gene expression in association with events that trigger smooth muscle hyperplasia. After balloon arterial denudation, there is a marked induction of IGF-I gene expression in the medial layer of the rat aorta, coincident with the peak time of SMC DNA synthesis (3-5). Estrogen and progesterone induce IGF-I and IGF-II mRNA levels in myometrial cells, consistent with the notion that these growth factors may help mediate sex-steroid-dependent SMC proliferation in the uterus (6-8). Bladder hypertrophy secondary to partial urethral ligation is also associated with increased IGF-I biosynthesis (9). It is unclear whether the local expression of IGF-I is critical to the development of smooth muscle hyperplasia in these tissue environments, or if it is simply a passenger event.

The object of the experiments described here was to examine the function of IGF-I in SMC by targeting its expression to the appropriate cells of transgenic mice. To select an appropri-

1. Abbreviations used in this paper: $\mathrm{CAT}$, cloramphericol acetyl transferase; $\mathrm{GH}$, growth hormone; SM, smooth muscle; SM-MHc, smooth muscle myosin heavy chain; SMC, smooth muscle cells. 
ate promoter capable of delivering SMC-specific expression, we considered information on the pattern of expression of several genes during vascular and intestinal development. Perhaps the most extensively studied of these is the smooth muscle (SM)- $\alpha$ actin gene, the expression of which is primarily restricted to SMC of adult rodents and rabbits (10-12). This gene is a member of the actin multigene family that consists of three classes of isoforms in vertebrates, named cytoplasmic, striated, and smooth muscle, based on the distribution of expression in adult animals. During early stages of embryogenesis, SM- $\alpha$ actin is also expressed in skeletal and cardiac muscle, and only becomes restricted to SMC during late fetal maturation $(10,13,14)$. By contrast, smooth muscle myosin heavy chain (SM-MHc) is thought to be a highly specific marker of the SMC lineage even during neonatal life, as it is expressed exclusively in the vasculature, intestine, lung, stomach, and uterus of the developing and the adult mice (15). However, preliminary evidence suggests that the activity of a SM-MHc promoter fragment coupled to luciferase is quite weak in transgenic mice (16). SM22 $\alpha$, a putative calcium binding protein, is expressed in cardiac, smooth, and skeletal muscle during embryogenesis $(17,18)$. A fragment of the SM22 $\alpha$ promoter directs reporter expression that is confined to arterial, but not venous or visceral smooth muscle cells. We elected to target IGF-I through mouse SM- $\alpha$ actin promoter constructs, primarily because of the expectation that their activity would manifest in most if not all SMC beds of adult animals, and thus allow us to examine the role of IGF-I on these cells in various tissue contexts. To our knowledge, this is the first report of overexpression of a functional protein capable of modifying the phenotype of SMC in transgenic mice. Our data shows that the SMP8-IGF-I transgene directs expression uniquely to SMC, where it promotes hyperplasia without affecting plasma IGF-I levels or total body weight. Quite unexpectedly, the pattern of organ remodeling evoked by IGF-I was distinct in the different smooth muscle tissue environments, resulting in concentric thickening of the muscular layers of the bladder and stomach, and longitudinal growth of the uterus and intestine.

\section{Methods}

Construction of SM- $\alpha$ actin/IGF-I and SM- $\alpha$ actin/cloramphericol acetyl transferase (CAT) fusion genes. The SMP8-IGF-I chimeric gene was constructed by fusing a fragment of the mouse SM- $\alpha$ actin $5^{\prime}$ end (SMP8) to a rat IGF-I cDNA. SMP8 consists of -1074 bp of the $5^{\prime}$ flanking region, the 63-bp 5'UT, and about $2.5 \mathrm{~kb}$ of the first intron (19-21). A 0.67-kb PvuII-BspM1 fragment from pIGF-I was cloned into pBluescript SK (-) at the EcoRv site. The resulting plasmid, prIGF-I, was cut with EcoR1, filled in with Klenow, and then restricted with BamH1 to release rat IGF-I cDNA ( $r I G F-I)$ containing the entire coding sequence, 57 bp of $5^{\prime}$-UT derived from exon 1 of the gene and 95 bp 3'-UT (22). A 0.24-kb Sau3 A1 fragment of the SV40 early polyadenylation signal (SV40-pA) was cloned into $\mathrm{pBluescript}$ SK (-) at the Pst1 site, and the resulting plasmid, pSV40-pA, was cut with Sma1 and EcoR1 to release the SV40-pA fragment. The rIGF-I and $S V 40-p A$ fragments were cloned into BamH1-EcoR1-digested pSMP8 by triple ligation to create pSMP8-IGF-I. pSMP8-CAT consisted of the indicated 3.6-kb promoter insert cloned into the Sph1BamH1 polylinker site of $p B L C A T 3$, upstream of the CAT reporter (23). The diagrams of the $p S M P 8-I G F-I$ and $p S M P 8-C A T$ constructs are shown in Fig. 1.

Generation of transgenic mice. The SMP8-IGF-I fusion gene was excised from $p S M P 8-I G F-I$ by restriction with SphI and EcoR1, whereas $p S M P 8-C A T$ was linearized with $\mathrm{SphI}$ before microinjection. The product was size separated and isolated from the agarose gel using the Geneclean II kit (Bio 101, La Jolla, CA). The DNA was sequentially extracted in phenol, chloroform, and ether, and then dialyzed against 5-mM Tris, pH 7.4, and 0.1-mM EDTA. The male pronuclei of fertilized eggs from either C3HEB/FEJ (for SMP8-CAT) or FVB-N (for SMP8-IGF-I) mouse strains were microinjected with 2 pl of linearized DNA at the transgenic mouse facility of the University of Cincinnati, Cincinnati, OH. Microinjected eggs were implanted into the oviduct of pseudopregnant female mice and carried to term.
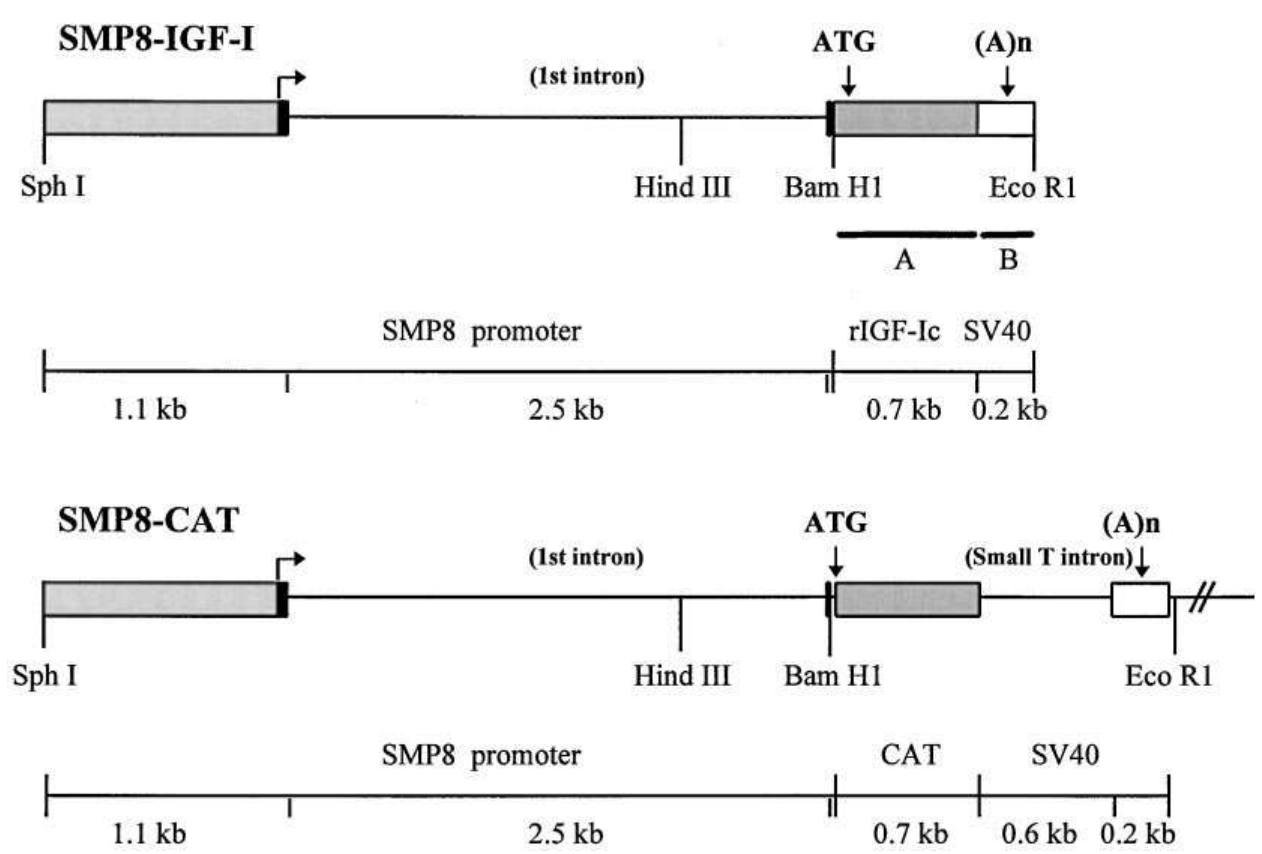

Figure 1. Linear map of the SMP8IGF-I and SMP8-CAT fusion genes. SMP8-IGF-I: the mouse SM- $\alpha$ actin promoter consisted of $-1074 \mathrm{bp}$ of $5^{\prime}$ flanking region (light gray box), the transcription start site, 48 bp of exon 1 (black box), the 2.5-kb intron 1 (line), and the 15-bp exon 2 (black box) of SM- $\alpha$ actin fused to a $0.7-\mathrm{kb}$ rat IGF-I cDNA (dark gray box), followed by a 240-bp SV40 early polyadenylation signal sequence (open box). SMP8$C A T$ : The SM- $\alpha$ actin promoter was cloned upstream of the chloramphenicol acetyltransferase reporter cDNA (dark gray box) in pBLCAT3 (23), the small $T$ intron (line), and the SV40 polyadenylation signals (open box). The following riboprobes were used for in situ hybridization: (a) complementary to rat IGF-I mRNA cross-hybridizes with mouse IGF-I mRNA; (b) complementary to SV40 poly (A) signal sequence (specific for transgene). 
Positive founders for SMP8-CAT or SMP8-IGF-I were identified by Southern blotting, and bred to wild-type C3HEB/FEJ or FVB mice, respectively. Transgene copy number was calculated by quantitative Southern blotting, using known amounts of the SMP8-IGF-I construct added to nontransgenic mouse genomic DNA as a standard according to the following formula: 7,200 bp (size of SMP8-IGF-I) $\times 5$ $\mu \mathrm{g} / 6 \times 10^{9} \mathrm{bp} /$ copy $=6 \times 10^{-6} \mu \mathrm{g} / \mathrm{copy}=6 \mathrm{pg} /$ copy .

Screening of transgenic mice. Heterozygotes and nontransgenic littermates from the F1 and subsequent generations were selected by Southern blotting of genomic DNA. Mouse tail tips $(\sim 1 \mathrm{~cm})$ were cut at $3 \mathrm{wk}$ of age, and digested with proteinase $\mathrm{K}(100 \mu \mathrm{g} / \mathrm{ml})$ in 0.5 $\mathrm{ml}$ of $10-\mathrm{mM}$ Tris, $\mathrm{pH} 8.0,100-\mathrm{mM}$ EDTA, $0.5 \%$ SDS at $50^{\circ} \mathrm{C}$ overnight. After phenol/chloroform/isoamyl alcohol (25:24:1, pH 8.0) extraction, the high molecular mass DNA was precipitated in isopropanol, washed in $70 \%$ ethanol, dissolved in $\mathrm{ddH}_{2} \mathrm{O}$ and stored at $4{ }^{\circ} \mathrm{C}$ until use. Southern analysis was performed as described (24). Briefly, $5 \mu \mathrm{g}$ of mouse genomic DNA was digested with HindIII at $37^{\circ} \mathrm{C}$ overnight, fractionated on a $1 \%$ agarose gel, transferred to a Hybond-N nylon membrane (Amersham Corp., Arlington Heights, IL), and then hybridized with a $0.7-\mathrm{kb}$ HindIII-XhoI fragment of mouse SM$\alpha$-actin genomic DNA labeled by random priming (Prime-It II kit; Stratagene, Inc., La Jolla, CA). Endogenous mouse SM- $\alpha$ actin alleles gave bands of $2.5 \mathrm{~kb}$, whereas the transgene was identified as an $\sim 5$-kb band.

RNA isolation and Northern blot analysis. Total RNA was isolated from tissues by a single step acid guanidinium thiocyanate-phenol-chloroform extraction method. Northern blots were performed as described (25). Briefly, $5 \mu \mathrm{g}$ of tissue total RNA was gel-separated, transferred to a nylon membrane, and then hybridized with random primed rat IGF-I cDNA. For standardization, blots were rehybridized with either human glyceraldehyde-3-phosphate dehydrogenase cDNA, when comparing within the same tissue type, or 18S rRNA, for comparisons between different tissues.

Allometry of SMP8-IGF-I transgenic mice. Transgenic mice and their nontransgenic littermates were killed by $\mathrm{CO}_{2}$ asphyxiation. After obtaining body weight, blood was collected by cardiac puncture and the serum stored at $-80^{\circ} \mathrm{C}$ until use. Organs of interest, except the aorta, were dissected, rinsed in ice-cold PBS, tissue-blotted, weighed, and immediately frozen in dry ice. Contents of stomach and small intestine were flushed out with PBS before weighing. A section of the arterial vessel, from the aortic arch to the level of femoral fork, was excised and placed in PBS. Adhering fat and connective tissue from the adventitia were scraped off under surgical microscope and the vessel was cleansed with a copious amount of PBS to remove any residual blood. Organs were immediately placed on dry ice and stored at $-80^{\circ} \mathrm{C}$ until use.

Tissue extraction and RIA for IGF-I. Tissues were placed in 1-ml ice-cold 1-M acetic acid and immediately homogenized for either $30 \mathrm{~s}$ (for bladder) or $1 \mathrm{~min}$ (for aorta) on ice with a Polytron PT3000 at full speed. After standing on ice for a further $2 \mathrm{~h}$, the tissue extracts were centrifuged in siliconized Eppendorf tubes at 18,000 $g$ for $1 \mathrm{~h}$ at $4^{\circ} \mathrm{C}$. The supernatants were carefully removed and aliquots were pipetted into polystyrene tubes to evaporate the solvent in a SpeedVac device (Savant Instruments, Inc., Farmingdale, NY) for $1 \mathrm{~h}$ without heating. Small aliquots of tissue extracts were also saved for measurement of total protein. Protein content was determined by the dyebinding method using BSA as a standard (26).

Recombinant human IGF-I (Austral Biologicals, San Ramon, CA) was iodinated according to the method described by Hill et al. (27). Briefly, $1 \mu \mathrm{g}$ of IGF-I in $0.1 \%$ HAc was iodinated with $1 \mathrm{mCi}$ $\left.{ }^{[25} \mathrm{I}\right] \mathrm{NaI}$ by addition of chloramine $\mathrm{T}(0.1 \mathrm{mg} / \mathrm{ml}$ in $0.3-\mathrm{M}$ sodium phosphate buffer, $\mathrm{pH}$ 7.6) in a stepwise manner over a period of 4.5 $\mathrm{min}$. The iodination reaction was terminated by sequentially adding a saturated tyrosine solution and $60-\mathrm{mM} \mathrm{NaI}$ to the reaction mixture, which was then applied to a pre-equilibrated Sephadex G-50 column and eluted with $4-\mathrm{mM} \mathrm{HCl}, 75-\mathrm{mM} \mathrm{NaCl}$, and $0.1 \%$ BSA to separate the iodinated peptide from the free ${ }^{125}$ I. The specific activity of the purified $\left[{ }^{125} \mathrm{I}\right]$ iodyltyrosyl-IGF-I was estimated at $320 \mu \mathrm{Ci} / \mu \mathrm{g}$.
For the IGF-I RIA, tissue extracts were resuspended in $0.03-\mathrm{M}$ sodium phosphate ( $\mathrm{pH} 7.4$ ) containing $0.05 \%$ Tween $20,0.02 \% \mathrm{NaN}_{3}$, $0.02 \%$ protamine sulfate, and 0.01-M EDTA, and assayed using a double antibody precipitation, nonequilibrium assay as described previously (28). The IGF-I antiserum was provided by Dr. L.E. Underwood (Pediatric Endocrinology, Chapel Hill, NC), and recombinant human IGF-I used as a standard. Tissue extracts and rodent sera gave parallel displacement curves as the human IGF-I standard.

Western ligand blotting. To determine tissue and serum content of IGFBPs, frozen tissues (bladders and aortas) were homogenized in PBS with 12-mM EDTA and 1-mM PMSF in a Polytron (model PT3000) at full speed on ice. Extracts were centrifuged at 100,000 $\mathrm{g}$ for $1 \mathrm{~h}$ at $4^{\circ} \mathrm{C}$, and the supernatant further concentrated in a Centricon-3 device (Amicon, Inc., Beverly, MA). Aliquots of the concentrated extracts were taken for protein assay. For Western ligand blotting, serum samples $(8 \mu \mathrm{l}$ each) were run on $7.5-20 \%$ gradient Laemmli gel and tissue extracts were run on $10-20 \%$ gradient or $10 \%$ Laemmli gels, under nonreducing conditions. After blotting, the nitrocellulose membrane was sequentially incubated with PBS- $0.1 \%$ Tween-20 and PBS-1\% BSA, and then with $24 \mu \mathrm{Ci}$ [ $\left.{ }^{125} \mathrm{I}\right] \mathrm{IGF}-1$ in 150 $\mathrm{ml}$ of PBS containing $1 \%$ BSA- $0.1 \%$ Tween- 20 at $4^{\circ} \mathrm{C}$ for $16 \mathrm{~h}$. After washing, the blots were dried and exposed to $\mathrm{x}$-ray film at $-70^{\circ} \mathrm{C}$. For tissue immunoblotting, the extracts were run on the same gels as used in ligand blotting but under reduced conditions. The blots were blocked with a TBS solution containing $0.05 \%$ Tween- 20 and nonfat dry milk and incubated with either 1:5000 rabbit anti-rat IGFBP4 antibody (516.F) or 1:1000 anti-human IGFBP-5 antibody (UBI, Lake Placid, NY) in the same blocking solution plus $0.01 \%$ thimerosal at room temperature for $16 \mathrm{~h}$. Membranes were washed and then incubated with 1:2500 goat anti-rabbit antibody (Santa Cruz Biotechnologies, Santa Cruz, CA) for $1 \mathrm{~h}$ at room temperature. The blots were detected with SuperSignal reagent (Pierce Chemical Co., Rockford, IL).

In situ hybridization. In situ hybridization was performed as described previously (29). Tissues dissected from animals at the indicated ages were fixed in $4 \%$ paraformaldehyde, saturated overnight with $30 \%$ sucrose in PBS, and frozen in OCT. Cryostat sections (7 $\mu \mathrm{m})$ were mounted on silane-coated slides. Sense and antisense cRNA probes for either rat IGF-I, that hybridizes to both endogenous mouse and transgenic rat IGF-I mRNA, and for a transgenespecific SV40 3'UT/polyA signal sequence, that recognizes only the exogenous mRNA, were labeled with $\left.{ }^{3}{ }^{3} \mathrm{~S}\right] \mathrm{rUTP}$, using a commercially available kit (Stratagene, Inc.). For generation of the antisense IGF-I riboprobe, the prIGF-I plasmid was linearized with BamHI, and transcribed with T7 RNA polymerase. The product was 733 bases long, 678 of which were complementary to transgene mRNA (see Fig. 1 , probe $A$ ). The sense IGF-I riboprobe was 732 bases long, and was obtained after linearizing the same vector with EcoRI, and transcribing with T3 RNA polymerase. Transgene-specific riboprobes were obtained from the $p S V 40-p A$ plasmid. The antisense probe was transcribed from HindIII-linearized plasmid with T7 polymerase, generating a 351 base riboprobe, 150 bases of which were complementary to the transgenic sequence (see Fig. 1, probe $B$ ). The 343 base sense riboprobe was generated from BamHI-linearized pSV40-pA with T3 polymerase. Hybridization was performed with a total of $5 \times 10^{5}$ to $1 \times 10^{6} \mathrm{cpm}$ in a final volume of $30 \mu \mathrm{l}$ per slide. The sections were hybridized overnight at $42^{\circ} \mathrm{C}$, treated with $50 \mu \mathrm{g} / \mathrm{ml}$ RNAase A (Sigma Chemical Co., St. Louis, MO) and $100 \mathrm{U} / \mathrm{ml}$ of RNAase T1 (Boehringer Mannheim Biochemicals, Indianapolis, IN) for $30 \mathrm{~min}$ at $37^{\circ} \mathrm{C}$, and washed to a final stringency of $0.1 \times$ standard citrate saline at $50^{\circ} \mathrm{C}$. Slides were dipped in NTB2 emulsion (Eastman Kodak Co., Rochester, NY), diluted $1: 1$ with $0.6 \mathrm{~mol} /$ liter ammonium acetate, exposed for 10-14 d, and developed in D19 developer (Eastman Kodak Co.). Sections were counterstained in hematoxilin and eosin and photographed under dark and brightfield illumination.

Tissue histomorphometry. Morphometry was done using NIH Image V1.61, an image processing and analysis program for the Macintosh. The tissue section images of SMP8-IGF-I transgenic mice (line 23423) and their age-matched nontransgenic controls were 
color-captured into the computer from the trichrome-stained sections through the microscope. After adjusting the image contrast, the area of interest was auto-outlined and the regions outside and inside of the area cleared. For example, the lumen area of aorta and intestine, and the thickness of the aortic media and the intestinal smooth muscle were calculated from a hypothetical perfect circle. The formulas are as follows: $\mathrm{Do}=\mathrm{P} / \pi ; \mathrm{Ai}=\mathrm{P}^{2} / 4 \pi-\mathrm{A} ; \mathrm{Di}=2(\mathrm{Ai} / \pi)^{0.5}, \mathrm{~T}=(\mathrm{Do}-$ $\mathrm{Di}) / 2$, where Do is the outer diameter, $\mathrm{P}$ is the perimeter, $\mathrm{A} i$ is the lumen area, A is the measured area, $\mathrm{Di}$ is the inner diameter, and $\mathrm{T}$ is the thickness of the muscular area.

CAT assay. Tissues from SMP8-CAT transgenic mice were dissected, rinsed in ice-cold PBS and immediately frozen in liquid $\mathrm{N}_{2}$ until assayed. Assays for CAT activity were performed essentially as described $(30,31)$ using ${ }^{14}[\mathrm{C}]$ chloramphenicol $(57 \mathrm{mCi} / \mathrm{mmol}$; Amersham Corp.) and equivalent amount of tissue extract (typically $1 \mu \mathrm{g}$ protein per $150 \mu \mathrm{l}$ of reaction volume). Acetylated products were separated by thin layer chromatography using Whatman silica gel 60A multichannel plates and exposed to Kodak XAR-5 film (Eastman Kodak Co.). TLC autoradiograms were analyzed using Image Quant software and laser densitometry (Molecular Dynamics, Sunnyvale, CA) to estimate the conversion of ${ }^{14}[\mathrm{C}]$ chloramphenicol to its acetylated derivatives.

Determination of myocyte number, tissue DNA, and RNA content. RNA and DNA were extracted from bladder, intestine, stomach, and brain tissues of SMP8-IGF-I transgenic mice and their nontransgenic littermates as described (32). The concentrations of the extracted nucleic acids were measured by UV absorption at $260 \mathrm{~nm}$. To verify RNA/DNA data, the myocyte number per surface area was directly counted on hematoxilin and eosin-stained slides using a grid as a reference point. For each tissue examined, a minimum of five fields $(\times 40)$ of five sections was counted.

Statistics. Comparisons were made using Student's $t$ test.

\section{Results}

The mouse SMP8 $\alpha$-actin promoter targets reporter activity to $S M C$-rich tissues of transgenic mice. Transcriptional activity directed by the -1074 bp SM- $\alpha$ actin promoter (SMP8) has been found to be restricted to myogenic lines in vitro (19-21). To determine if this promoter fragment also conferred selective expression in vivo, CAT activity was measured in tissue extracts of transgenic mice derived from a representative founder carrying the SMP8-CAT fusion gene. Acetylation activity was highest in SMC-rich tissues (stomach, aorta, mesenteric artery), intermediate in lung and kidney, and negligible in cardiac ventricle and liver (Fig. 2).

Generation of SMP8-IGF-I mice, and examination of transgene expression. Eight SMP8-IGF-I founder animals were obtained from a total of 42 mice screened. The percentage of transgenic offspring in the F1 generation indicated that three of the eight founders were mosaics. In subsequent generations, matings of hemizygous transgenic mice with controls produced about $50 \%$ transgenic offspring, with equal sex distribution. Five transgenic lines were further propagated for more complete analysis.

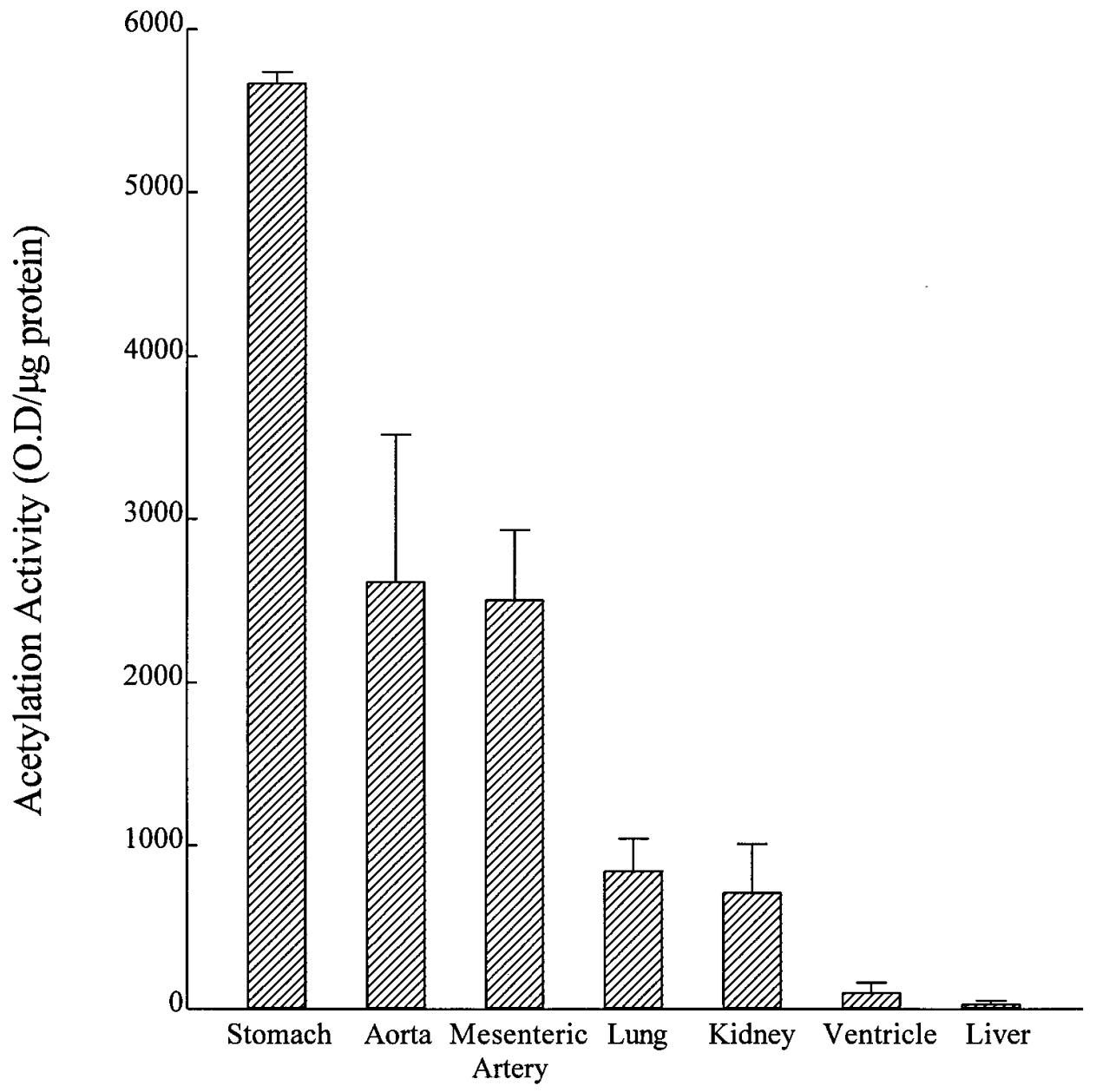

Figure 2. Acetylation activity of selected tissues of SMP8-CAT transgenic mice (line 2). Data (mean \pm SEM) represent the optical density of autoradiograms of thin layer chromatograms of the indicated tissue extracts harvested from three mice, normalized per microgram of total protein. 

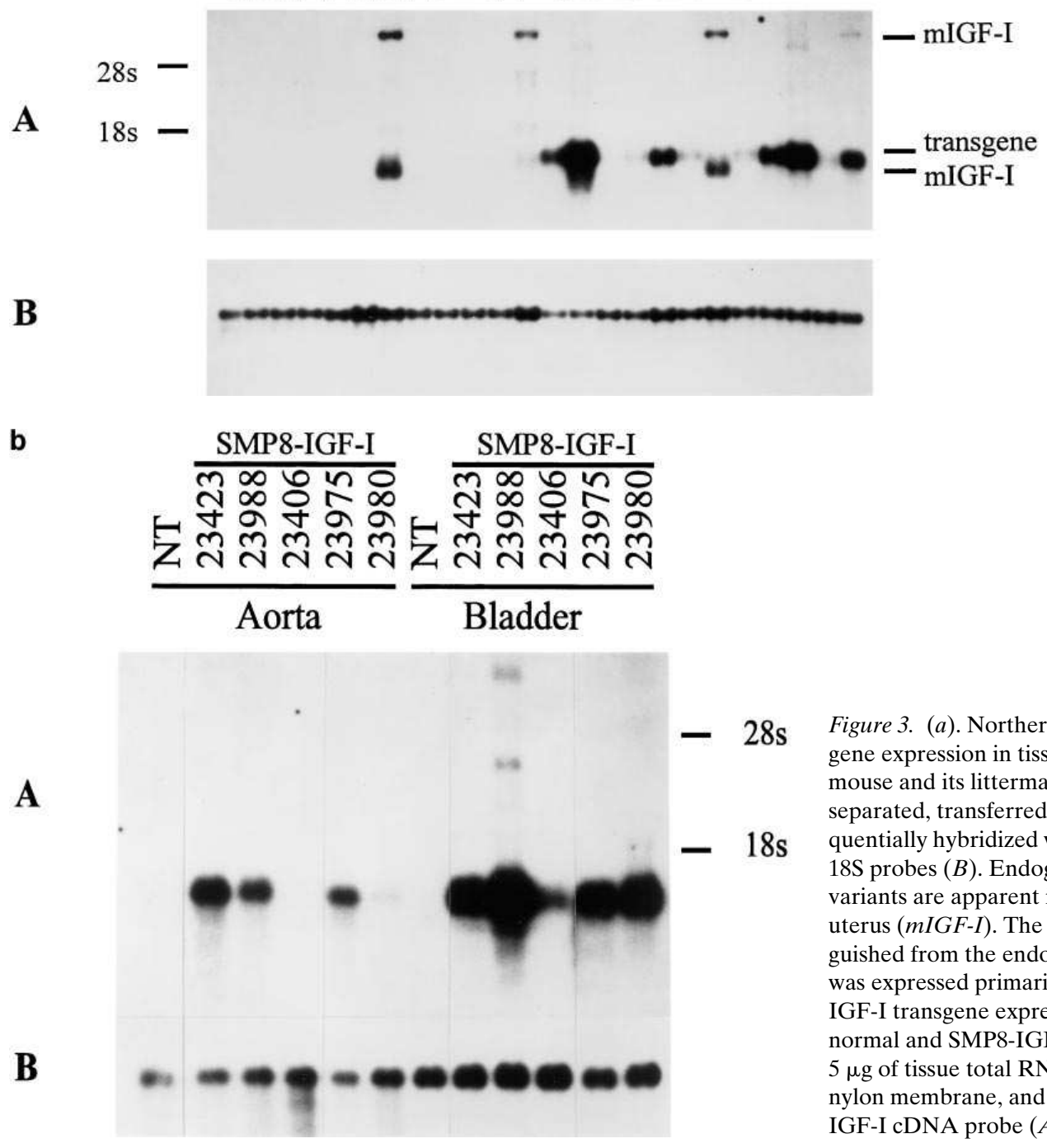

Figure 3. (a). Northern blot analysis of SMP8-IGF-I transgene expression in tissues from a representative transgenic mouse and its littermate. $5 \mu \mathrm{g}$ of tissue total RNA was gelseparated, transferred to a nylon membrane, and then se-

18s quentially hybridized with a rat IGF-I cDNA $(A)$ and human $18 \mathrm{~S}$ probes $(B)$. Endogenous mouse IGF-I mRNA splice variants are apparent in liver and to a lesser extent in the uterus ( $m I G F-I)$. The IGF-I transgene mRNA was distinguished from the endogenous forms by size (transgene), and was expressed primarily in SMC-rich tissues. (b): SMP8IGF-I transgene expression in aorta and bladder tissues of normal and SMP8-IGF-I transgenic mice from several lines. $5 \mu \mathrm{g}$ of tissue total RNA was gel-separated, transferred to a nylon membrane, and then sequentially hybridized with rat IGF-I cDNA probe $(A)$ and human GAPDH probe $(B)$.

The tissue distribution of expression of endogenously produced and transgenic IGF-I mRNA is shown in Fig. $3 A$. RNA was obtained from tissues dissected from a 5-wk-old SMP8IGF-I transgenic female and a nontransgenic littermate. IGF-I mRNA was abundant in the liver of the nontransgenic mouse, and otherwise detected only in the uterus. By contrast, the IGF-I transgene was detected at high levels in bladder, aorta, intestine, stomach, uterus, and spleen. The size of the transgenic IGF-I mRNA was slightly greater than that of the endogenous transcript, presumably because of differences in the composition of the $3^{\prime} \mathrm{UT}$ and polyA region of the transgenic message. Transgene expression in skeletal muscle and in the heart was barely detectable. Overexpression of the exogenous IGF-I mRNA was consistently found exclusively in SM-rich tissues of transgenic mice derived from all founder lines tested, although to varying degrees, as shown in Fig. 3 . There was no correlation between transgene copy number in the various lines (which ranged from 2 to 20 copies per cell), and expression of IGF-I mRNA (not shown).

IGF-I content of tissue extracts was measured by RIA, after separation of IGF binding proteins by acidification. The appropriateness of the separation was verified by demonstrating that the immunoreactive fraction in the acidified tissue extract coeluted with recombinant IGF-I after separation through a Sephadex G50 column. IGF-I content of aorta and bladder was many-fold higher in SMP8-IGF-I mice as compared to their nontransgenic littermates at the two time points tested (5.5 and $10 \mathrm{wk}$ ) (Fig. $4 \mathrm{~A}$ ). There was no significant difference in plasma IGF-I levels in the SMP8-IGF-I transgenic line $\mathrm{f} 23423$ (Fig. $4 \mathrm{~B}$ ). There was a tendency towards higher plasma IGF-I levels in the transgenic line f23988, that was not statistically significant. As will be discussed below, line f23988 


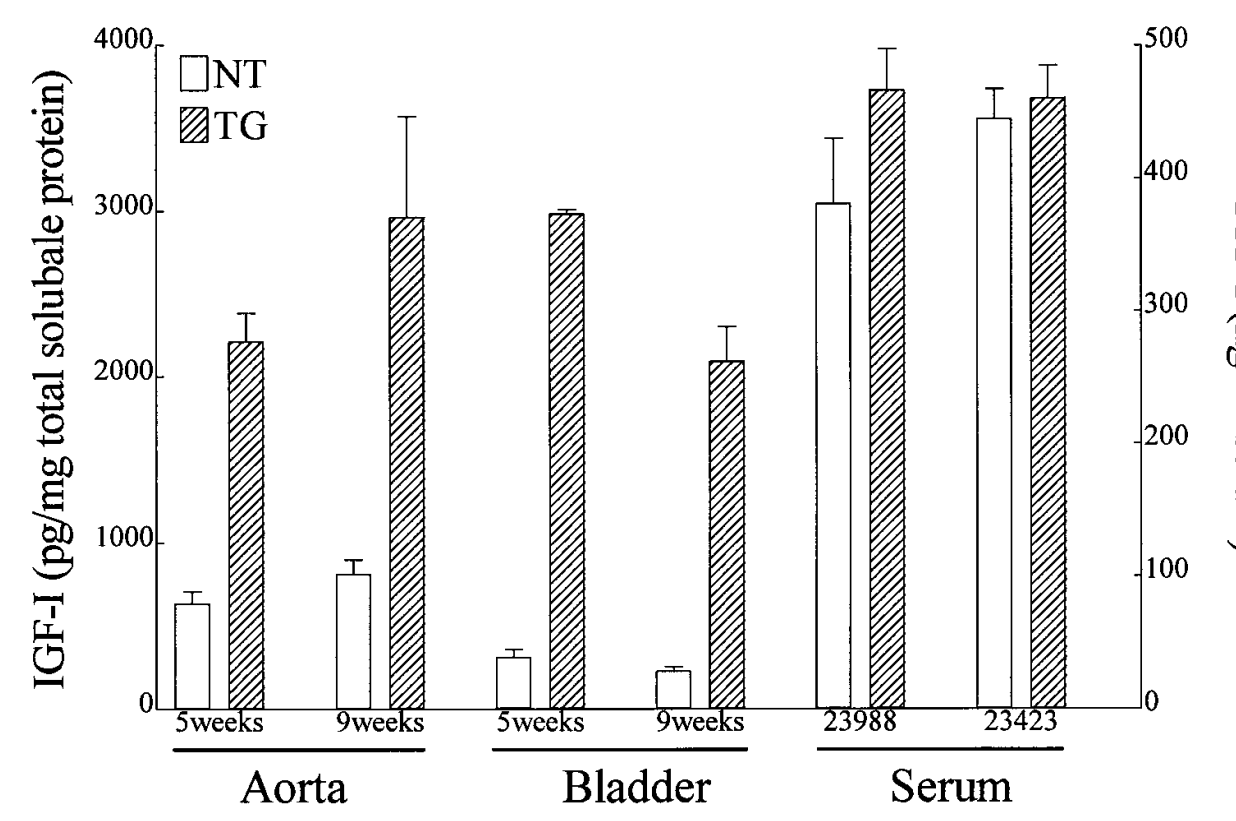

Figure 4. (Left) Tissue IGF-I concentrations in aorta and bladder of SMP8-IGF-I transgenic mice line $23423(T G)$ and their nontransgenic littermates $(N T)$. Tissue protein extracts were acidified to separate them from binding proteins, and the supernatants were subjected to RIA. Results are expressed as picograms of IGF-I per milligram of total acid-solubilized protein from individual tissues. Bars represent mean \pm SEM from tissues obtained from 5- $(n=3)$ and 9-wk-old $(n=4)$ SMP8-IGF-I TG and NT littermates. (Right) Serum IGF-I concentrations in SMP8IGF-I transgenic mice $(T G)$ derived from two transgenic lines (f23988 and f23423) and their nontransgenic littermates $(N T)$. Binding proteins were removed from serum samples by acidification before RIA. Results are expressed as nanograms of IGF-I per milliliter of serum. Data represent $n=4$ for each TG or NT group. There was no significant difference of serum IGF-I between TG and NT mice of either line.

was the only one displaying a modest increase in total body and carcass weight, suggesting that the overexpression of IGF-I in these animals was not entirely confined to paracrine tissue environments.

Total body weight and allometry of SMP8-IGF-I transgenic mice demonstrates selective growth of bladder, stomach, uterus, intestine, and aorta. Total body, carcass, and individual organ weights were determined in mice derived from two of the lines (f23423 and f23988), at two different time points. As shown in Fig. 5, f23423 mice had no change in total body weight compared to their nontransgenic littermates. By contrast, f23988 mice had a modest increase in total body weight that was already apparent at $4 \mathrm{wk}$ of age, and which was sustained at about 115 and $120 \%$ that of nontransgenic males, and females, respectively. In the 23423 line there was a selective increase in the wet weight of the aorta, bladder, intestine, and stomach in both male and female mice. In addition, females had a marked increase in uterine weight that was already apparent before puberty (Table I). As mentioned above, mice from the 123988 line were the only ones to exhibit a modest increase in total body weight. However, even in these animals the increase in the weight of the bladder, intestine, stomach, and uterus was markedly disproportionate to total body weight gain, as demonstrated after controlling for this variable. Mice from f23421 and $\mathrm{f} 23408$ exhibited similar findings (not shown).

Transgene expression localizes exclusively to smooth muscle cells. The cellular localization of expression of IGF-I mRNA was examined first by in situ hybridization with a rat IGF-I cRNA, that recognized both the endogenous as well as the transgenic gene product. As reported previously, the major site of IGF-I gene expression in normal mice was in the parenchymal cells of the liver (Fig. $6 A$ ). Expression of IGF-I

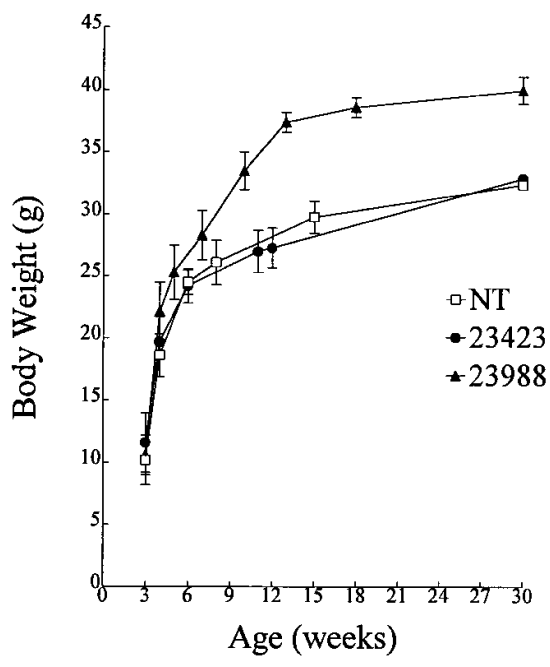

1430

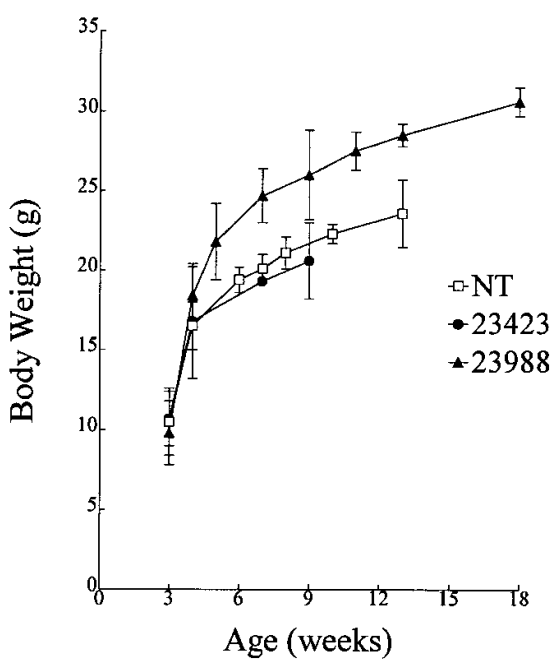

Figure 5. Growth curves of male (left) and female (right) SMP8-IGF-I transgenic mouse lines $\mathrm{f} 23988$ and $\mathrm{f} 23423$ and nontransgenic controls $(N T)$. 
Table I. Total Body and Tissue Weights of SMP8-IGF-I Mice and Age-matched Nontransgenic Controls

\begin{tabular}{|c|c|c|c|c|c|c|c|c|c|c|c|c|c|c|c|}
\hline \multirow[b]{2}{*}{ Line } & & & \multirow[b]{2}{*}{$n$} & \multicolumn{12}{|c|}{$($ Mean+SD) } \\
\hline & & & & $\begin{array}{l}\text { Body } \\
(\mathrm{g})\end{array}$ & $\begin{array}{l}\text { Carcass } \\
(\mathrm{g})\end{array}$ & $\begin{array}{l}\text { Aorta } \\
(\mathrm{mg})\end{array}$ & $\begin{array}{l}\text { Bladder } \\
\text { (mg) }\end{array}$ & $\begin{array}{l}\text { Brain } \\
(\mathrm{mg})\end{array}$ & $\begin{array}{l}\text { Heart } \\
(\mathrm{mg})\end{array}$ & $\begin{array}{l}\text { Intestine } \\
(\mathrm{mg})\end{array}$ & $\begin{array}{l}\text { Kidney } \\
(\mathrm{mg})\end{array}$ & $\begin{array}{l}\text { Lung } \\
(\mathrm{mg})\end{array}$ & $\begin{array}{l}\text { Spleen } \\
\text { (mg) }\end{array}$ & $\begin{array}{l}\text { Stomach } \\
(\mathrm{mg})\end{array}$ & $\begin{array}{l}\text { Uterus } \\
(\mathrm{mg})\end{array}$ \\
\hline & & NT & 8 & $25.3 \pm 1.6$ & $16.9 \pm 1.1$ & $6.7 \pm 1.3$ & $13.2 \pm 4.1$ & $399.3 \pm 33.5$ & $124.7 \pm 13.6$ & $1374.5 \pm 79.7$ & $468.1 \pm 44.8$ & $144.3 \pm 23.8$ & $92.5 \pm 9.9$ & $126.0 \pm 18.2$ & \\
\hline & M & $\mathrm{T}$ & 4 & $25.9 \pm 0.9$ & $16.4 \pm 0.4$ & $9.9 \pm 2.5$ & $30.3 \pm 13.9$ & $382.5 \pm 13.6$ & $108.3 \pm 6.2$ & $1833.4 \pm 48.1$ & $461.1 \pm 28.7$ & $134.3 \pm 17.2$ & $115.1 \pm 19.3$ & $163.1 \pm 11.3$ & \\
\hline 23423 & & $\begin{array}{l}\text { T/NT\% } \\
\mathrm{p}\end{array}$ & & 102.6 & 97.0 & $\begin{array}{c}148.7 \\
0.0288\end{array}$ & $\begin{array}{c}228.5 \\
0.0152\end{array}$ & 95.8 & 86.8 & $\begin{aligned} & 133.4 \\
< & 0.0001\end{aligned}$ & 98.5 & 93.1 & $\begin{array}{c}124.5 \\
0.0338\end{array}$ & $\begin{array}{c}129.4 \\
0.0066\end{array}$ & \\
\hline $9 \mathrm{wk}$ & & NT & 6 & $20.1 \pm 0.8$ & $13.3 \pm 0.6$ & $5.8 \pm 1.1$ & $8.4 \pm 1.3$ & $401.6 \pm 32.2$ & $94.7 \pm 3.4$ & $1301.0 \pm 94.7$ & $311.6 \pm 23.8$ & $120.3 \pm 9.4$ & $92.8 \pm 5.9$ & $117.2 \pm 11.5$ & $68.6 \pm 20.6$ \\
\hline & $\mathrm{F}$ & $\mathrm{T}$ & 4 & $20.6 \pm 2.4$ & $12.7 \pm 1.7$ & $9.1 \pm 1.1$ & $16.5 \pm 2.9$ & $374.2 \pm 32.8$ & $92.2 \pm 6.1$ & $1705.4 \pm 135.3$ & $318.1 \pm 43.4$ & $124.9 \pm 18.9$ & $78.2 \pm 35.7$ & $152.1 \pm 21.2$ & $124.9 \pm 14.3$ \\
\hline & & T/NT\% & & 102.4 & 95.9 & 155.6 & 196.3 & 93.2 & 97.3 & 131.1 & 102.1 & 103.8 & 84.3 & 129.7 & 182.1 \\
\hline & & $\mathrm{p}$ & & & & 0.0033 & 0.0004 & & & 0.0011 & & & & 0.0170 & 0.0028 \\
\hline & & NT & 17 & $29.8 \pm 2.1$ & $20.3 \pm 1.5$ & $8.9 \pm 1.7$ & $24.2 \pm 10.6$ & $438.1 \pm 30.6$ & $139.4 \pm 13.3$ & $1433.6 \pm 129.1$ & $592.5 \pm 76.5$ & $155.6 \pm 16.5$ & $111.2 \pm 32.1$ & $144.3 \pm 13.6$ & \\
\hline & M & $\mathrm{T}$ & 7 & $35.6 \pm 2.0$ & $23.1 \pm 1.3$ & $10.8 \pm 3.5$ & $54.7 \pm 19.1$ & $411.8 \pm 45.2$ & $150.0 \pm 12.3$ & $2334.8 \pm 198.2$ & $631.0 \pm 65.5$ & $165.1 \pm 16.6$ & $139.6 \pm 33.3$ & $248.0 \pm 18.5$ & \\
\hline 23988 & & T/NT\% & & 119.6 & 113.6 & 122.3 & 225.8 & 94.0 & 107.6 & 162.9 & 106.5 & 106.1 & 125.5 & 171.9 & \\
\hline & & $\mathrm{p}$ & & 0.0002 & 0.0063 & & 0.0019 & & & $<0.0001$ & & & & $<0.0001$ & \\
\hline $15 \mathrm{wk}$ & & NT & 9 & $23.0 \pm 1.7$ & $15.5 \pm 1.0$ & $7.4 \pm 1.4$ & $10.7 \pm 2.7$ & $419.1 \pm 27.6$ & $107.3 \pm 8.1$ & $1329.1 \pm 92.8$ & $376.9 \pm 39.5$ & $143.3 \pm 21.2$ & $97.1 \pm 9.1$ & $140.6 \pm 10.9$ & $81.4 \pm 13.2$ \\
\hline & $\mathrm{F}$ & $\mathrm{T}$ & 3 & $27.9 \pm 1.8$ & $17.7 \pm 1.3$ & $8.2 \pm 0.9$ & $19.2 \pm 1.4$ & $434.3 \pm 32.3$ & $112.0 \pm 5.4$ & $2383.4 \pm 55.0$ & $396.0 \pm 11.1$ & $160.2 \pm 15.1$ & $125.8 \pm 11.8$ & $247.7 \pm 18.0$ & $178.3 \pm 4.4$ \\
\hline & & T/NT\% & & 121.2 & 114.4 & 110.5 & 179.7 & 103.6 & 104.4 & 179.3 & 105.1 & 111.8 & 129.6 & 176.3 & 219.2 \\
\hline & & $\mathrm{p}$ & & 0.0029 & 0.0200 & & 0.0007 & & & $<0.0001$ & & & 0.0026 & $<0.0001$ & $<0.0001$ \\
\hline
\end{tabular}

$N T$, nontransgenic; T, SMP8-IGF-I transgenic. Wet weight of tissue was performed as described in Methods. 
mRNA in normal uterus, stomach, and intestine of nontransgenic mice was primarily confined to the epithelial layer (Fig. 6 $C)$, with only modest levels present in smooth muscle cells. Similarly, IGF-I mRNA levels were very low in arterial smooth muscle cells (not shown, and reference 3). In marked
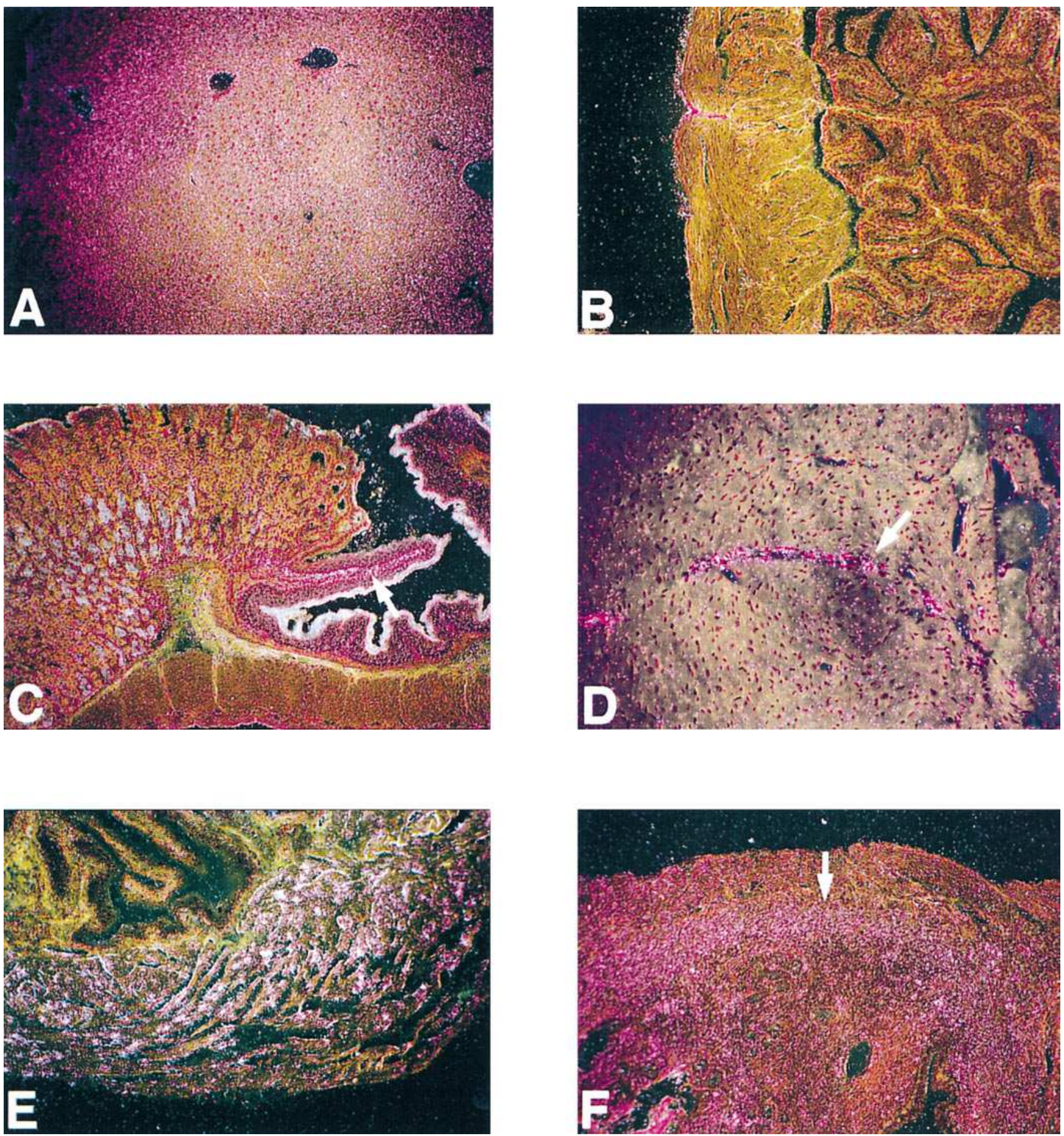

Figure 6. In situ hybridization of SMP8-IGF-I mice and nontransgenic controls. ( $A$ ) Liver, nontransgenic; IGF-I riboprobe, endogenous expression is diffuse in hepatocytes. $(B)$ Bladder, nontransgenic, IGF-I riboprobe, no significant endogenous expression in either the mucosa or muscle layers. $(C)$ Stomach, nontransgenic; showing junction between forestomach (right half) and gastric glandular mucosa. There is a weak signal (arrow) in the lamina propria of the foregut mucosa. No signal in the muscular layers of the wall of the stomach. (D) Coronary artery, SMP8IGF-I; SV40 probe, arrow showing signal in the wall of the artery, none in surrounding cardiac muscle. (E) Bladder, SMP8-IGF-I; SV40 probe, strong signal localized to the SMC of the bladder wall, no signal in the mucosa. $(F)$ Uterus, SMP8-IGF-I, SV40 probe, most signal localizes to smooth muscle cells in the wall of the uterus (arrow). Scattered positive cells in stroma. No signal in epithelial layer. 

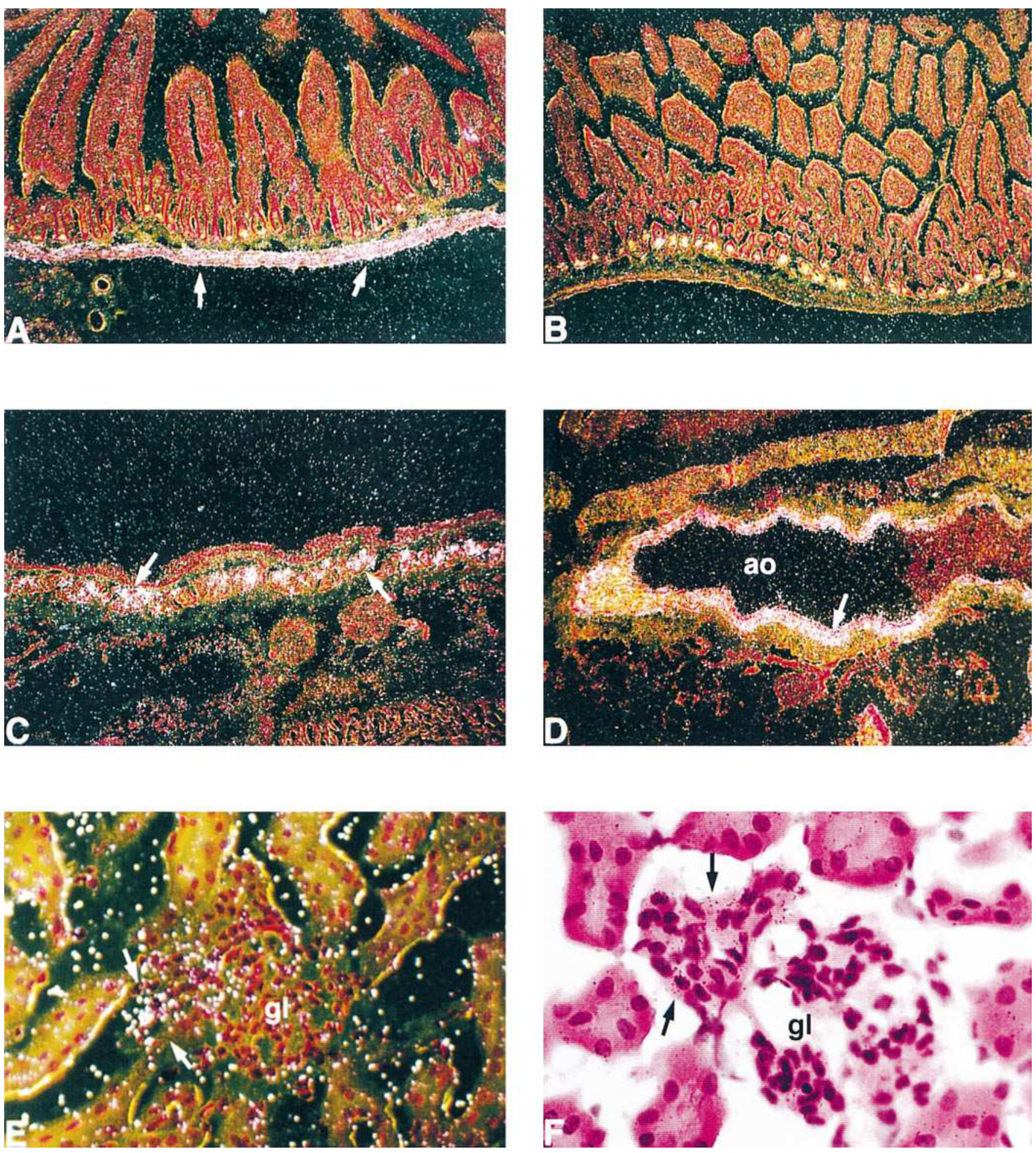

Figure 7. Expression of the IGF-I transgene in SMP8-IGF-I transgenic mice. (A) Section of small intestine from a transgenic mouse line that has been hybridized with the antisense probe for SV40. There is strong signal (arrows) that localizes to the smooth muscle cells in the wall of the bowel. (B) Section of small intestine from a nontransgenic mouse which was also hybridized with the SV40 probe. No signal is detected in the nontransgenic animals. The yellow-green color in the crypts of the mucosal glands in both the transgenic and nontransgenic tissue is autofluorescence from the Paneth cell granules and does not represent hybridization signal. $(C)$ Longitudinal section through the proximal bronchus of a transgenic mouse. The SV40 signal (arrows) localizes to the SM cell layers in the wall of the bronchus. (D) Longitudinal section through the aorta $(a o)$ of a transgenic mouse with strong SV40 signal (arrow) in the wall of the aorta. (E) Section of renal cortex from a transgenic mouse. The SV40 signal (arrow) localizes to the region of the juxtaglomerular apparatus but not in the glomerulus. $(F)$ Bright field image of the kidney with signal (arrows, black grains) that localize to the juxtaglomerular apparatus but not the glomerulus $(g l)$. ( $A-E$, darkfield; $F$, bright field; counterstain hematoxylin and eosin; $A-D \times 100, E \times 400, F \times 600)$. 
tissues from transgenic animals. Transgene expression was observed in the media of all arterial beds examined. There was high level expression in the aortic media (Fig. $7 \mathrm{D}$ ). Fig. $6 \mathrm{D}$ shows a longitudinal section of a coronary artery with a strong signal along the margin of the vessel. Notably, there was no hybridization in the surrounding myocardial cells. Similarly, there was no transgene localization to skeletal myocytes. Smooth muscle cells of the bladder, uterus and intestine also showed marked hybridization to the transgene-specific riboprobe (Figs. 6, $E$ and $F$, and $7 A$ ). Bronchial SMC also demonstrated expression of the transgene (Fig. $7 C$ ). Interestingly, there was no expression in glomerular mesangial cells, however, there was a clear signal in the juxtaglomerular apparatus (Fig. 7, $E$ and $F$ ).

Tissue morphometry reveals distinct patterns of organ remodeling. The localization of the IGF-I transgene uniquely to SMC, coupled to the evidence that tissues rich in SMC exhibited selective weight gain, prompted a more detailed investigation of the anatomical and histological characteristics of the affected organs. The urinary bladder had the most dramatic weight changes (Table I), and was also the site of highest transgene expression in all lines tested. As shown in Fig. $8 \mathrm{~A}$, the major feature of the transgenic bladders was a marked increase in the thickness of the muscular layer. This change was attributable to increased cell mass, and not to a greater deposition of extracellular matrix, as demonstrated by trichrome staining (not shown). The muscular layer of the stomach was also more cellular and markedly thicker in the SMP8-IGF-I transgenic animals (not shown).

The uterine phenotype of the SMP8-IGF-I transgenic mice was in marked contrast to that of the bladder. Gross anatomical examination revealed a striking increase in the length of the uterine horns (Fig. $8 \mathrm{~B}$ ). Histological and morphometric evaluation indicated that the surface area of the myometrial layer in transverse sections was not significantly different from that of nontransgenic littermates. Thus, SMC growth in the uterus manifested entirely in an increase in the overall length, but not the width, of the myometrium. This phenomenon was also apparent in the small intestine. As shown in Fig. $8 \mathrm{C}$ and Table II, the small bowel of SMP8-IGF-I transgenic mice was about $23 \%$ longer than that of nontransgenic littermates. Although the surface area of the muscularis layer in transverse sections was also modestly increased, this clearly does not explain the major increase in intestinal weight and length in the transgenic animals (Table II). Interestingly, the increase in intestinal length occurred entirely postnatally: intestinal length was $8.3 \pm 0.7 \mathrm{~cm}$ in SMP8-IGF-I transgenics $1 \mathrm{~d}$ after birth $(n=$ $5)$, and $8.9 \pm 0.6 \mathrm{~cm}$ in nontransgenic littermates $(n=4)$.

The effect on medial aortic smooth muscle cells was assessed by histomorphometry of transverse sections taken at identical sites from aortas of SMP8-IGF-I transgenic mice and their littermates $(n=5)$. Overall aortic medial area and thickness were significantly greater in the IGF-I overexpressing animals compared to their littermates (Table II).

Overexpression of the IGF-I transgene is associated with smooth muscle hyperplasia. The increase in SMC mass in SMP8-IGF-I transgenic mice was due to hyperplasia, and not hypertrophy, as determined by RNA/DNA and protein/DNA ratios in the targeted tissues. As shown in Table III, there was no difference in these parameters in the bladder, uterus, or intestine of transgenic animals. As these tissues contain a variable admixture of SMC with other cell types, the presence of hyperplasia was also confirmed by counting myocytes on hematoxilin and eosin-stained slides of transverse sections of bladder and aorta at a magnification of 40. Myocyte counts per surface area were not significantly different after examining five fields from five sections of each of these tissues from four separate SMP8-IGF-I transgenic and nontransgenic littermates (not shown), indicating that the average size of the smooth muscle cells was not different between transgenics and controls.

Expression of IGF binding proteins in SMP8GF-I transgenic mice. The biological activity of IGF-I is modified by locally produced IGFBPs, that vary in their expression and

Table II. Morphometry of Aorta and Intestine from SMP8-IGF-I Transgenic Mice and their Nontransgenic Controls

\begin{tabular}{|c|c|c|c|c|c|c|c|}
\hline \multirow[b]{2}{*}{ Aorta } & \multicolumn{4}{|c|}{$($ Mean+SD) } & & & \\
\hline & $\begin{array}{l}\text { Medial area } \\
(\mu \mathrm{m})^{2}\end{array}$ & $\begin{array}{l}\text { Outer perimeter } \\
\qquad(\mu \mathrm{m})\end{array}$ & $\begin{array}{l}\text { Lumen area } \\
\qquad(\mu \mathrm{m})^{2}\end{array}$ & $\begin{array}{l}\text { Medial thickness } \\
\qquad(\mu \mathrm{m})\end{array}$ & & & \\
\hline NT & $62431 \pm 8897$ & $2206 \pm 142$ & $326625 \pm 41004$ & $29 \pm 3$ & & & \\
\hline $\mathrm{T}$ & $76792 \pm 2551$ & $2334 \pm 125$ & $358256 \pm 46750$ & $35 \pm 2$ & & & \\
\hline T/NT\% & 123.0 & 105.8 & 109.7 & 117.6 & & & \\
\hline \multirow[b]{3}{*}{ Intestine } & 0.0146 & & & 0.0113 & & & \\
\hline & & & & $($ Mean+SD) & & & \\
\hline & $\begin{array}{l}\text { Length } \\
(\mathrm{cm})\end{array}$ & $\begin{array}{l}\text { Muscular area } \\
\qquad(\mu \mathrm{m})^{2}\end{array}$ & $\begin{array}{l}\text { Muscular perimeter } \\
\qquad(\mu \mathrm{m})\end{array}$ & $\begin{array}{l}\text { Muscular thickness } \\
\qquad(\mu \mathrm{m})\end{array}$ & $\begin{array}{l}\text { Mucosal area } \\
\qquad(\mu \mathrm{m})^{2}\end{array}$ & $\begin{array}{c}\text { Mucosal perimeter } \\
(\mu \mathrm{m})\end{array}$ & $\begin{array}{l}\text { Mucosal thickness } \\
\qquad(\mu \mathrm{m})\end{array}$ \\
\hline NT & $44.8 \pm 1.0$ & $140873 \pm 17797$ & $7383 \pm 933$ & $19 \pm 3$ & $1246038 \pm 163161$ & $6939 \pm 894$ & $206 \pm 50$ \\
\hline $\mathrm{T}$ & $55.4 \pm 1.9$ & $180452 \pm 11909$ & $7068 \pm 203$ & $26 \pm 1$ & $1214942 \pm 385581$ & $6626 \pm 222$ & $205 \pm 71$ \\
\hline T/NT\% & 123.7 & 128.1 & 95.7 & 132.6 & 97.5 & 95.5 & 99.4 \\
\hline$P$ & $<0.0001$ & 0.0120 & & 0.0080 & & & \\
\hline
\end{tabular}

$N T$, Nontransgenic; $T$, SMP8-IGF-I transgenic; $n=5$. Comparison between male SMP8-IGF-I transgenic mice (line 23423) and nontransgenic agematched controls. 

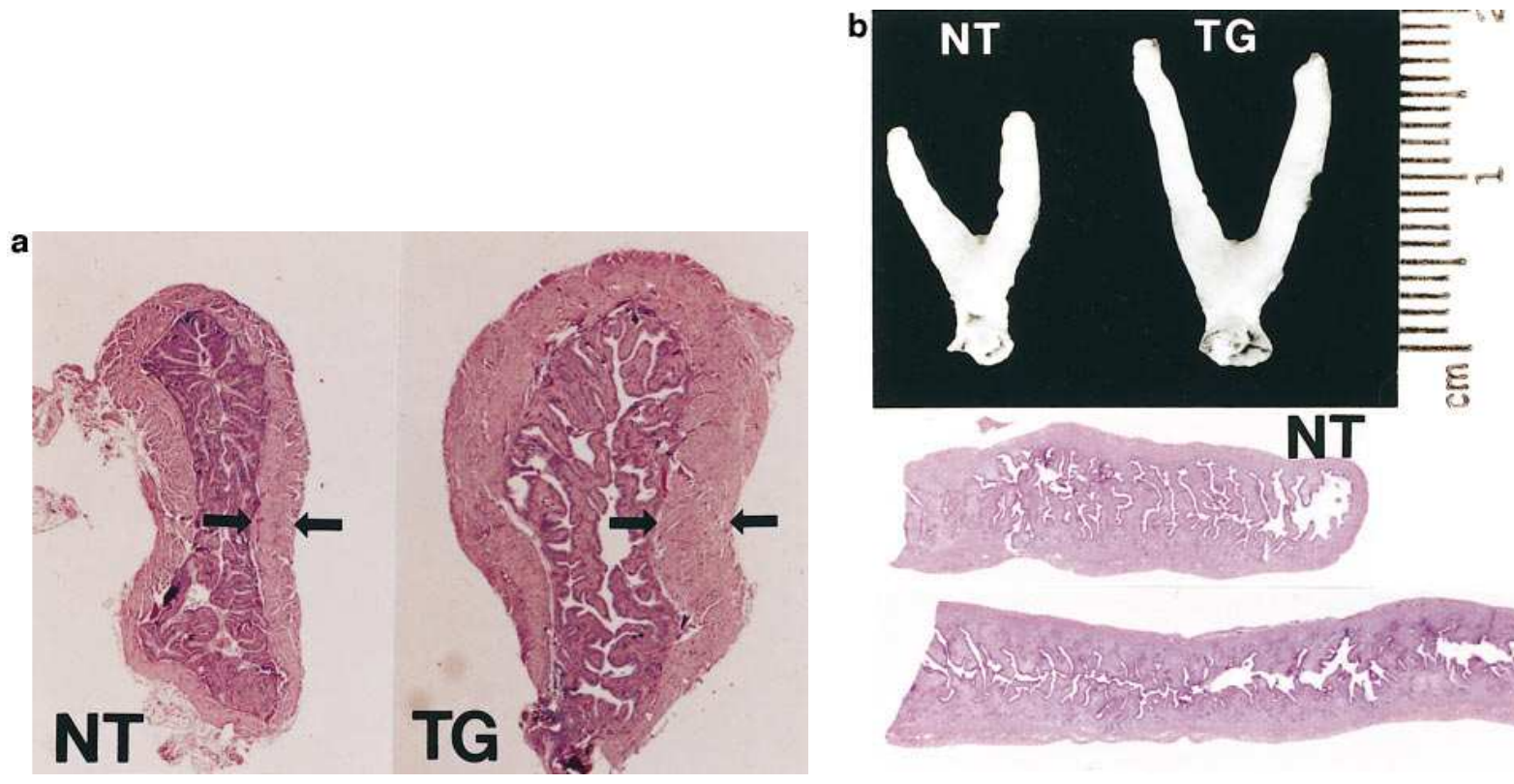

TG
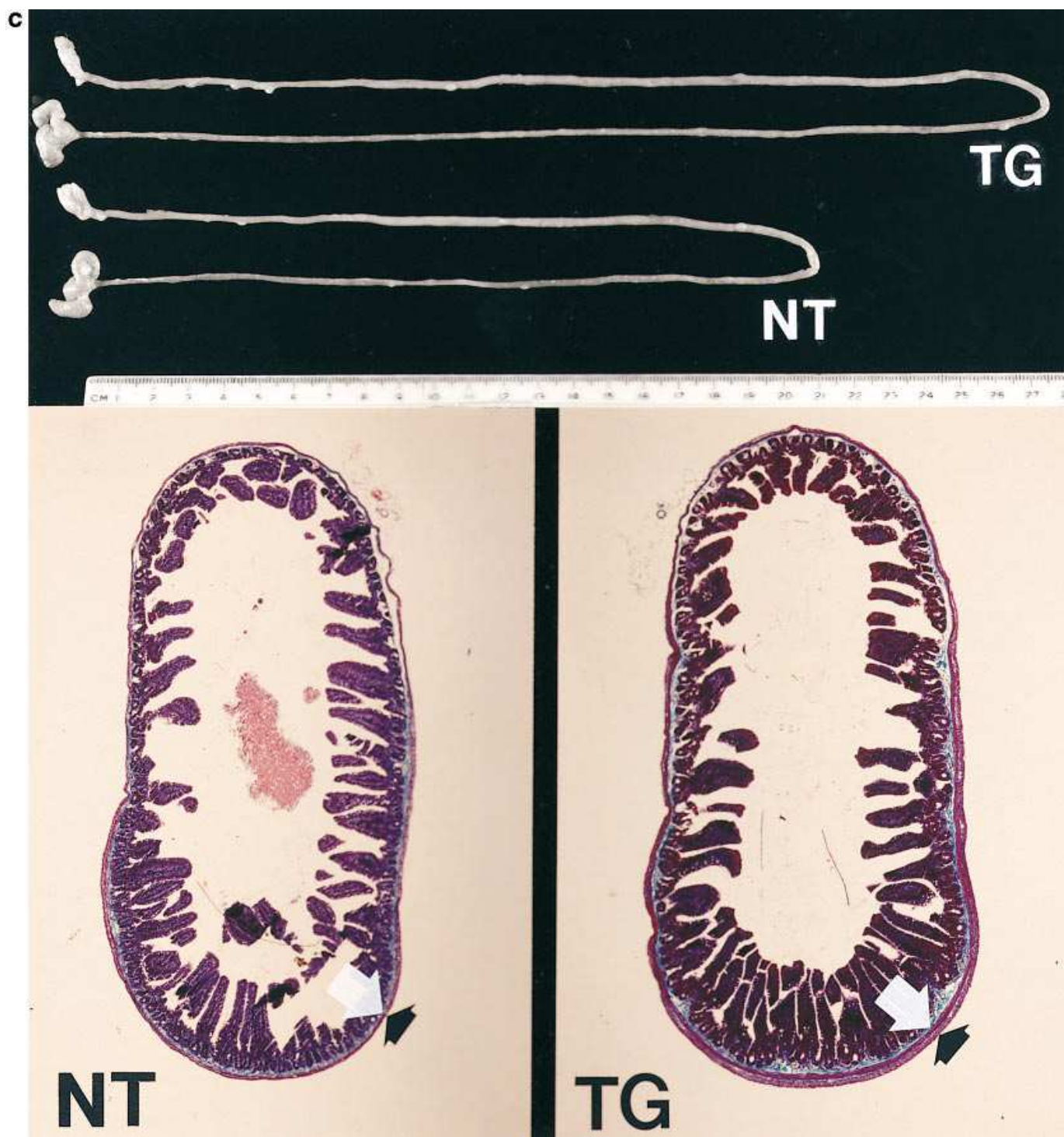

Figure 8. Gross anatomy and low-power magnification sections of selected tissues of SMP8-IGF-I transgenic mice (TG) and nontransgenic littermates $(N T)$. (a) Thickening of muscular layer of bladder in SMP8-IGF-I mice (H \& E stain). (b) Longitudinal growth of uterine horns (top), with no change in thickness of myometrial layer (bot tom). (c) (top) Gross view of small intestine from gastric junction to cecum, shows lengthening of small bowel in TG mouse. (Bottom) Trichrome staining of transverse section of intestine. Arrows indicate muscularis layer. The epithelial layer of NT mouse was disrupted during fixation. 
Table III. Relative Content of DNA and RNA

(RNA/DNA) in Tissues from SMP8-IGF-I

Mice and their Nontransgenic Controls

\begin{tabular}{lcccc}
\hline Sample & Bladder & Intestine & Stomach & Brain \\
\hline NT & $3.02 \pm 0.43$ & $0.75 \pm 0.05$ & $1.15 \pm 0.25$ & $0.86 \pm 0.03$ \\
T & $3.15 \pm 0.67$ & $0.66 \pm 0.10$ & $1.02 \pm 0.07$ & $0.98 \pm 0.18$
\end{tabular}

$N T$, nontransgenic; $T$, SMP8-IGF-I transgenic; $n=4$; values are mean $\pm \mathrm{SD}$

abundance in different tissue environments. Western ligand blotting of aorta, bladder and uterus of nontransgenic and transgenic mice showed a very similar pattern of abundance of IGFBPs (Fig. 9). Circulating IGFBP levels as determined by Western ligand blotting were also unchanged, as were IGFBP-4 levels measured by RIA (not shown). IGF-I has been reported to induce IGFBP-5 gene transcription in porcine aortic SMC (33). IGF-I also induces IGFBP-5 gene expression in skeletal myoblasts as part of its effects on their overall program of differentiation in vitro (34). There was no significant change in IGFBP-5 mRNA levels in bladder, aorta or stomach of SMP8IGF-I mice as compared to nontransgenic age- and sexmatched controls ( $n=4$, not shown). Accordingly, immunoreactive IGFBP-5 levels were not increased in the bladders of SMP8-IGF-I mice (Fig. 10). Thus, chronic IGF-I overexpression does not recapitulate some of the effects seen acutely in

A

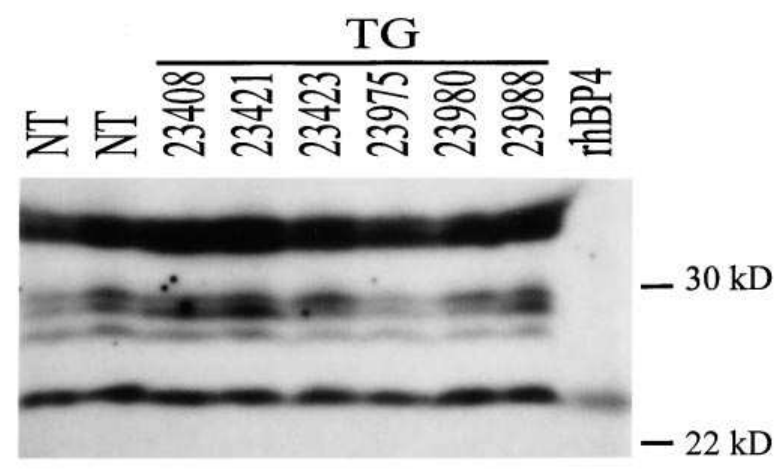

B

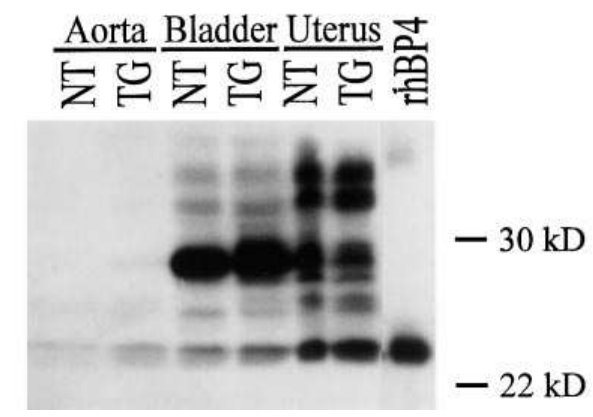

Figure 9. Serum and tissue IGFBP levels in SMP8-IGF-I transgenic mice $(T G)$ and their nontransgenic littermates $(N T)$. (A) $8 \mu$ lof serum from two NT or six TG mice derived from different lines; and (B) $150 \mu \mathrm{g}$ of total soluble protein extracts from aorta, bladder, and uterus were analyzed by Western ligand blotting with [ ${ }^{125}$ I]IGF-I. $r h B P 4$, recombinant human IGFBP-4.

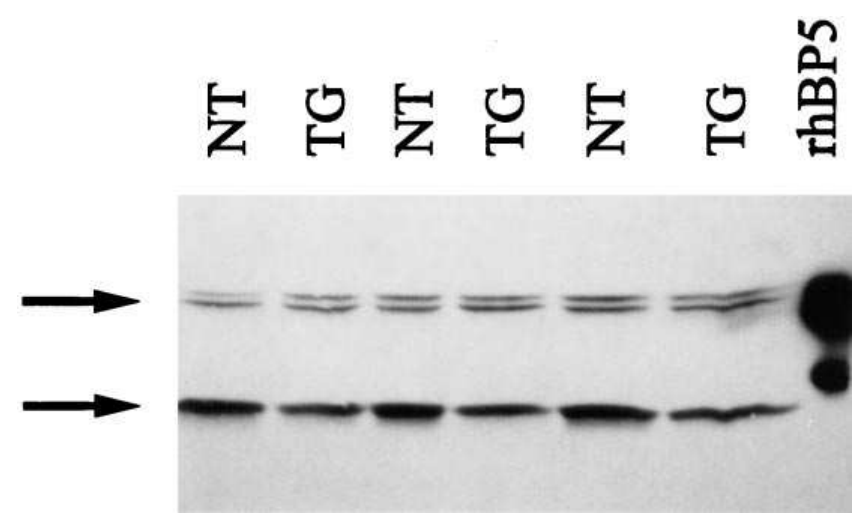

Figure 10. Western blot of bladder tissue extracts from three SMP8IGF-I mice $(T G)$ and three nontransgenic $(N T)$ controls blotted with anti-IGFBP-5 antibody. Top arrow indicates band corresponding to IGFBP-5 (doublet may represent glycosylated and unglycosylated forms). Lower arrow points to proteolytic fragment of IGFBP-5. Note lower abundance of this band in TG bladder, consistent with protection from proteolysis by local IGF-I excess. $r h B P 5$, recombinant human IGFBP-5.

cultured SMC. However, the abundance of a $23 \mathrm{kD}$ proteolytic fragment of IGFBP-5 is clearly decreased in bladders of transgenic mice, supporting the observation that IGF-I may protect IGFBP-5 from proteolysis (Fig. 10). There was also no significant difference in tissue IGFBP-4 mRNA or protein levels in the transgenic mice.

IGF-I has been reported to inhibit SM- $\alpha$ actin gene accumulation in adult cardiac myocytes in vitro (35). We found no effect on either SM- $\alpha$ actin or SM- $\gamma$ actin mRNA in either bladder, uterus, intestine, or aorta of the IGF-I transgenic mice compared to their littermates (not shown).

\section{Discussion}

SMP8-IGF-I transgenic mice show targeted overexpression of IGF-I in SMC beds with the following hierarchy: bladder $>$ stomach $>$ aorta $=$ uterus $>$ intestine. There was little or no transgene mRNA detected in liver (the major source of endogenous expression of IGF-I) or in skeletal or cardiac muscle. Indeed, in situ hybridization demonstrates that the expression of the transgene is confined to SMC in all tissues examined. The transgene-derived IGF-I remains paracrine, although one line showing high levels of overexpression had a tendency towards higher serum IGF-I concentration, and evidence of whole body weight gain. Allometry of SMP8-IGF-I transgenic mice demonstrated a selective weight gain only in bladder, uterus, stomach, intestine, and aorta. The pattern of increase in SMC mass was specific to the tissue environment: i.e., longitudinal growth of horns in the uterus, elongation of the intestine, concentric thickening of the muscular layers of the bladder and stomach, increased diameter, lumen and medial layer of the aorta.

This paper provides evidence for the first time that the phenotype of SMC can be selectively modified through a transgenic approach. Several groups have provided important insights into the properties of genes considered to be markers for SMC (SM22 $\alpha$, SM-MHc), and characterized the activities of their respective promoters during development $(15,17,18,36)$. 
These studies were performed using reporter gene constructs, and did not attempt to target a protein capable of modifying the biological activity of SMC. Although expression of SM- $\alpha$ actin has been extensively studied during embryogenesis, the function of its promoter in vivo has not been studied. The $-1074 \mathrm{bp} 5^{\prime}$ flanking region of mouse SM- $\alpha$ actin contains an evolutionary conserved motif that represses expression in nonmyogenic fibroblast cells, a serum response element, as well as six E-box motifs, all of which mediate high level expression in postconfluent BC3H1 myoblasts and aortic SMC (19-21). In addition, the first intron has been proposed to contain additional motifs important for SMC-specific transcription. The expression of SM- $\alpha$ actin in the mouse is detectable in SMC precursors at about E10. However, it is well recognized that SM- $\alpha$ actin is transiently expressed during embryogenesis in cardiomyoblasts, myotomal myoblasts and myotubes, and only becomes restricted to SMC postnatally $(10,37)$. We do not know whether this particular SM- $\alpha$ actin promoter fragment was also transcriptionally active in heart and skeletal muscle during a window of time during development. Although the type I IGF receptor is expressed in skeletal muscle and heart at the appropriate period of rat embryogenesis (day 13) (38), there was no obvious phenotype in striated muscle in the transgenic animals. Whether this is due to a lack of effect of IGF-I in these tissues over this period, or to inactivity of the promoter fragment remains to be studied. The pattern of expression of the IGF-I transgene in the adult animals is consistent with the tissue distribution of wild-type $\alpha$ actin gene expression after birth. Furthermore, the SMC hyperplasia and organ remodeling were also confined to these tissues. Indeed, based on measurements of intestinal length, it appears that most effects of IGF-I on SMC growth took place postnatally.

The role of IGF-I on prenatal growth and differentiation has been clarified by the phenotype of mice carrying null mutations of the IGF-I, IGF-II, and IGF-I receptor genes (39-41). IGF-I appears to play a central role in fetal growth, as the birth weight of the IGF-I (-/-) animals was about $60 \%$ that of the wild-type controls starting at E13.5. Many of these mice died, and the survivors had evidence of hypoplasia of numerous tissues, including bone, muscle, and the nervous system. At birth, SMP8-IGF-I mice did not have an obvious phenotype (i.e., intestinal lengthening), suggesting that ambient IGF-I or IGF-II concentrations to which fetal SMC are exposed are already quite high, and no additional prenatal growth can be derived by further selective overexpression in these cells.

IGF-I has a prominent role in mediating the postnatal growth-promoting effects of growth hormone (GH). Several transgenic approaches have been used to elucidate the relative contributions of GH and IGF-I to somatic growth (41-46). Mice carrying copies of rat $\mathrm{GH}$ fused to the mouse metallothionein-1 (MT-1) gene promoter had elevated circulating $\mathrm{GH}$ and IGF-I levels, and grew significantly larger than normal control mice starting at $3 \mathrm{wk}$ of age. Mice carrying a MT1-IGF-I also had elevated IGF-I, but with reduced plasma GH levels, and also exhibited longitudinal growth (47). Part of the increased weight was due to changes in skeletal muscle and connective tissue mass, as well as selective organomegaly of spleen, pancreas, brain, and kidney. Data on targeted expression of IGF-I in particular cell types are more limited. Overexpression of IGF-I in cardiac myocytes has been achieved in transgenic mice through a rat $\alpha$ myosin heavy chain $(\alpha \mathrm{MHc})-$ IGF-I chimeric gene (48). These animals developed cardiac myocyte hyperplasia and increased heart weight that manifested after $\sim 10 \mathrm{wk}$. By contrast, overexpression of IGF-I in skeletal myocytes through the avian skeletal $\alpha$ actin gene resulted in SMC hypertrophy (49). Primary cultures of myoblasts from these transgenic mice had precocious expression of myogenin and MyoD, and of the gene products activated by these transcription factors, suggesting that IGF-I may have accelerated skeletal muscle differentiation. SMC are not subject to terminal differentiation, and it is perhaps not surprising that SMC from SMP8-IGF-I mice were hyperplastic. The expression of $\alpha$ actin and $\gamma$-enteric actin mRNAs was not significantly different in transgenics versus littermates in any of the SMC-tissue beds, and $\alpha$ actin expression was not detectable in striated muscle postnatally, indicating that IGF-I did not introduce major disruptions in their developmental program. Whether there was a more subtle acceleration or delay of muscle development that was later compensated for is unknown.

The pattern of organ remodeling resulting from IGF-I overexpression in SMC was particularly remarkable. Whereas the SMC layer of bladder, aorta, and stomach grew in thickness, the small intestine and the uterine horns grew primarily in length. The mechanisms of this intriguing phenotype are not known. The possibility that the transgene may have been differentially expressed in the circular versus the longitudinal layers of the respective tissues deserves consideration. Uterine mesenchymal cells remain randomly oriented during the late fetal period. Postnatally, three layers become apparent. The circular middle layer and the outer longitudinal layer express $\alpha$ actin in a similar temporal pattern (50). Furthermore, in situ hybridization of tissues of transgenic mice demonstrated a fairly uniform level of expression of the transgene among the SMC layers, indicating that the remodeling effects were not due to targeted expression to a specific SMC tissue compartment. Similarly, studies on the distribution of IGF-I receptors in the intestine and uterus of several species have consistently shown higher levels in the epithelial layers, but homogeneous distribution between SMC compartments $(8,51,52)$. The IGF-I receptor is also evenly expressed in the rat arterial media (3). Hence, it appears unlikely that the pattern of remodeling can be ascribed to differential transgenic IGF-I expression, or to the distribution of the IGF-I receptor. With the possible exception of the uterus, the pattern of organ growth resembles that observed after certain pathophysiological stimuli, or in other nontargeted transgenic models. Transgenic mice that ubiquitously overexpress either bovine GH (53) or IGF-I (54) under control of the MT- 1 promoter exhibit increased mucosal thickness and an increase in intestinal length. After small bowel resection, mice treated systemically with IGF-I analogs that bind poorly to binding proteins for one week had a dosedependent increase in intestinal length (55). It is possible that the drive for intestinal lengthening in the SMP8-IGF-I mice results at least in part from diffusion of IGF-I from the SMC compartment to the intestinal mucosa. The appearance of the bladder in the SMP8-IGF-I transgenic mice resembles that described in models of obstructive bladder hypertrophy, where IGF-I has been proposed to play a pathogenic role (9).

Besides modulating IGF action, the overall abundance and distribution of IGFBPs can in turn be affected by ambient IGF-I levels. Overexpression of IGF-I was not associated with changes in tissue IGFBP4 or 5 mRNA or protein levels in any of the SMC tissue beds. Similarly, the abundance of IGFBPs as determined by Western-ligand blotting was comparable be- 
tween transgenic mice and their littermates. This is of interest, as transcription of IGFBP-5 is induced by IGF-I in rat SMC in vitro (33). This suggests that chronic overexpression of IGF-I in vivo cannot further increase IGFBP-5 gene expression in SMC. IGF-I has also been shown to protect IGFBP-5 from proteolysis, although this varies depending on the cell type (56). The bladders from the SMP8-IGF-I had a lower abundance of the 23-kD IGFBP-5 proteolytic product, indicating that IGF-I indeed protects IGFBP-5 from cleavage by its specific protease.

We and others have reported that the expression of IGF-I is markedly induced after balloon denudation of the rat aorta, femoral and carotid arteries, peaking 3-7 d after the procedure (3-5). The expression of the IGF-type I receptor is reciprocally decreased in the artery media, consistent with downregulation after ligand binding (3). Similarly, IGF-I gene expression accompanies bladder- and estrogen-induced myometrial hyperplasia. The individual contribution of a single growth factor in a complex tissue response is hard to elucidate, because of the participation of multiple mitogens, many of which may partially overlap in their function. In addition to the data reported here, we have also established lines of transgenic mice overexpressing IGFBP-4 under control of the SMP8 promoter, and these animals have a reciprocal phenotype (Wang, J., W. Niu, Y. Nikiforov, S. Naito, S. Chernausek, D. Witte, D. LeRoith, A. Strauch, and J. Fagin, unpublished observations). Availability of mice with strictly paracrine alterations in the expression of members of the IGF family of proteins will allow a better analysis of their function under basal conditions and after various perturbations in vivo. Use of SM- $\alpha$ actin 5' flanking sequences to target expression in transgenic mice should also be valuable to explore the function of other gene products in SMC tissues in vivo.

\section{Acknowledgments}

We are grateful to Dr. John Newman, of the University of Cincinnati Transgenic Mouse Core Facility for generating the transgenic mice, and to Kathy Saalfeld and Pamela Groen for assistance with the in situ hybridization experiments.

This paper was supported by National Institutes of Health Grant HL43802. J.A. Fagin is a recipient of an Established Investigator Award of the American Heart Association and Bristol-Myers Squibb.

\section{References}

1. Clemmons, D.R., and J.J. Van Wyk. 1985. Evidence for a functional role of endogenously produced somatomedin-like peptides in the regulation of DNA synthesis in cultured human fibroblasts and porcine smooth muscle cells. J. Clin. Invest. 75:1914-1918.

2. Clemmons, D.R. 1985. Exposure to platelet-derived growth factor modulates the porcine aortic smooth muscle cell response to somatomedin-C. Endocrinology. 117:77-83.

3. Khorsandi, M.J., J.A. Fagin, D. Giannella-Neto, J.S. Forrester, and B. Cercek. 1992. Regulation of insulin-like growth factor-I and its receptor in rat aorta after balloon denudation. Evidence for local bioactivity. J. Clin. Invest. 90: 1926-1931.

4. Cercek, B., M.C. Fishbein, J.S. Forrester, R.H. Helfant, and J.A. Fagin. 1990. Induction of insulin-like growth factor I messenger RNA in rat aorta after balloon denudation. Circ. Res. 66:1755-1760.

5. Hayry, P., M. Myllarniemi, E. Aavik, S. Alatalo, P. Aho, S. Yilmaz, A. Raisanen-Sokolowski, G. Cozzone, B.A. Jameson, and R. Baserga. 1995. Stabile D-peptide analog of insulin-like growth factor-1 inhibits smooth muscle cell proliferation after carotid ballooning injury in the rat. FASEB (Fed. Am. Soc. Exp. Biol.) J. 9:1336-1344.

6. Murphy, L.J. 1991. Estrogen induction of insulin-like growth factors and myc proto-oncogene expression in the uterus. J. Steroid Biochem. Mol. Biol. 40:
223-230.

7. Ghahary, A., S. Chakrabarti, and L.J. Murphy. 1990. Localization of the sites of synthesis and action of insulin-like growth factor-I in the rat uterus. Mol. Endocrinol. 4:191-195.

8. Tang, X.M., M.J. Rossi, B.J. Masterson, and N. Chegini. 1994. Insulinlike growth factor I (IGF-I), IGF-I receptors, and IGF binding proteins 1-4 in human uterine tissue: tissue localization and IGF-I action in endometrial stromal and myometrial smooth muscle cells in vitro. Biol. Reprod. 50:1113-1125.

9. Chen, Y., K.E. Bornfeldt, A. Arner, E. Jennische, U. Malmqvist, B. Uvelius, and H.J. Arnqvist. 1994. Increase in insulin-like growth factor I in hypertrophying smooth muscle. Am. J. Physiol. 266:E224-229.

10. Woodcock-Mitchell, J., J.J. Mitchell, R.B. Low, M. Kieny, P. Sengel, L. Rubbia, O. Skalli, B. Jackson, and G. Gabbiani. 1988. Alpha-smooth muscle actin is transiently expressed in embryonic rat cardiac and skeletal muscles. Differentiation. 39:161-166.

11. Skalli, O., J. Vandekerckhove, and G. Gabbiani. 1987. Actin-isoform pattern as a marker of normal or pathological smooth-muscle and fibroblastic tissues. Differentiation. 33:232-238.

12. Owens, G.K. 1995. Regulation of differentiation of vascular smooth muscle cells. Physiol. Rev. 75:487-517.

13. McHugh, K.M., K. Crawford, and J.L. Lessard. 1991. A comprehensive analysis of the developmental and tissue-specific expression of the isoactin multigene family in the rat. Dev. Biol. 148:442-458.

14. Sawtell, N.M., and J.L. Lessard. 1989. Cellular distribution of smooth muscle actins during mammalian embryogenesis: expression of the alpha-vascular but not the gamma-enteric isoform in differentiating striated myocytes. $J$. Cell Biol. 109:2929-2937.

15. Miano, J.M., P. Cserjesi, K.L. Ligon, M. Periasamy, and E.N. Olson. 1994. Smooth muscle myosin heavy chain exclusively marks the smooth muscle lineage during mouse embryogenesis. Circ Res. 75:803-812.

16. Franz, W.M., O.J. Mueller, M. Fleischmann, G. Brem, P. Babij, and H.A. Katus. 1996. The $2.3 \mathrm{~kb}$ smooth muscle myosin-heavy-chain promoter directs gene expression to the vascular system of transgenic mice. American Heart Association 69th Scient. Sess. 964 (Abstr.)

17. Li, L., J.M. Miano, B. Mercer, and E.N. Olson. 1996. Expression of the SM22alpha promoter in transgenic mice provides evidence for distinct transcriptional regulatory programs in vascular and visceral smooth muscle cells. $J$. Cell Biol. 132:849-859.

18. Li, L., J.M. Miano, P. Cserjesi, and E.N. Olson. 1996. SM22 alpha, a marker of adult smooth muscle, is expressed in multiple myogenic lineages during embryogenesis. Circ. Res. 78:188-195.

19. Cogan, J.G., S. Sun, E.S. Stoflet, L.J. Schmidt, M.J. Getz, and A.R. Strauch. 1995. Plasticity of vascular smooth muscle alpha-actin gene transcription. Characterization of multiple, single-, and double-strand specific DNAbinding proteins in myoblasts and fibroblasts. J. Biol. Chem. 270:11310-11321.

20. Foster, D.N., B. Min, L.K. Foster, E.S. Stoflet, S. Sun, M.J. Getz, and A.R. Strauch. 1992. Positive and negative cis-acting regulatory elements mediate expression of the mouse vascular smooth muscle alpha-actin gene. J. Biol. Chem. 267:11995-12003.

21. Min, B.H., D.N. Foster, and A.R. Strauch. 1990. The 5'-flanking region of the mouse vascular smooth muscle alpha-actin gene contains evolutionarily conserved sequence motifs within a functional promoter. J. Biol. Chem. 265: $16667-16675$

22. Yang, H., M.L. Adamo, A.P. Koval, M.C. McGuinness, H. Ben-Hur, Y. Yang, D. LeRoith, and C.T. Roberts. 1995. Alternative leader sequences in insulin-like growth factor I mRNAs modulate translational efficiency and encode multiple signal peptides. Mol. Endocrinol. 9:1380-1395.

23. Luckow, B., and G. Schutz. 1987. CAT constructions with multiple unique restriction sites for the functional analysis of eukaryotic promoters and regulatory elements. Nucleic Acids Res. 15:5490.

24. Southern, E. 1979. Gel electrophoresis of restriction fragments. Methods Enzymol. 68:152-176.

25. Shackleford, G.M., and H.E. Varmus. 1987. Expression of the protooncogene int -1 is restricted to postmeiotic male germ cells and the neural tube of mid-gestational embryos. Cell. 50:89-95.

26. Bradford, M.M. 1976. A rapid and sensitive method for the quantitation of microgram quantities of protein utilizing the principle of protein-dye binding. Anal. Biochem. 72:248-254.

27. Hill, D.J., C. Camacho-Hubner, P. Rashid, A.J. Strain, and D.R. Clemmons. 1989. Insulin-like growth factor (IGF)-binding protein release by human fetal fibroblasts: dependency on cell density and IGF peptides. J. Endocrinol. 122:87-98.

28. Furlanetto, R.W., L.E. Underwood, J.J. Van Wyk, and A.J. D'Ercole. 1977. Estimation of somatomedin-C levels in normals and patients with pituitary disease by radioimmunoassay. J. Clin. Invest. 60:648-657.

29. Witte, D.P., B.J. Aronow, J.K. Dry, and J.A. Harmony. 1994. Temporally and spatially restricted expression of apolipoprotein $\mathrm{J}$ in the developing heart defines discrete stages of valve morphogenesis. Dev. Dyn. 201:290-296.

30. Gorman, C.M., L.F. Moffat, and B.H. Howard. 1982. Recombinant genomes which express chloramphenicol acetyltransferase in mammalian cells. Mol. Cell. Biol. 2:1044-1051.

31. Ausubel, F.M., R. Brent, R.E. Kingston, D.D. Moore, J.G. Seidman, 
J.L. Smith, and K. Struhl. 1995. Current Protocols in Molecular Biology. In Anonymous John Wiley and Sons. 60-72.

32. Shibko, S., P. Koivistoinen, C.A. Tratnyek, A.R. Newhall, and L. Friedman. 1967. A method for sequential quantitative separation and determination of protein, RNA, DNA, lipid, and glycogen from a single rat liver homogenate or from a subcellular fraction. Anal. Biochem. 19:514-528.

33. Duan, C., S.B. Hawes, T. Prevette, and D.R. Clemmons. 1996. Insulinlike growth factor-I (IGF-I) regulates IGF-binding protein-5 synthesis through transcriptional activation of the gene in aortic smooth muscle cells. J. Biol. Chem. 271:4280-4288.

34. Rotwein, P., P.L. James, and K. Kou. 1995. Rapid activation of insulinlike growth factor binding protein-5 gene transcription during myoblast differentiation. Mol. Endocrinol. 9:913-923.

35. Donath, M.Y., J. Zapf, M. Eppenberger-Eberhardt, E.R. Froesch, and H.M. Eppenberger. 1994. Insulin-like growth factor I stimulates myofibril development and decreases smooth muscle alpha-actin of adult cardiomyocytes. Proc. Natl. Acad. Sci. USA. 91:1686-1690.

36. Katoh, Y., E. Loukianov, E. Kopras, A. Zilberman, and M. Periasamy. 1994. Identification of functional promoter elements in the rabbit smooth muscle myosin heavy chain gene. J. Biol. Chem. 269:30538-30545.

37. Babai, F., J. Musevi-Aghdam, W. Schurch, A. Royal, and G. Gabbiani. 1990. Coexpression of alpha-sarcomeric actin, alpha-smooth muscle actin and desmin during myogenesis in rat and mouse embryos I. Skeletal muscle. Differentiation. 44:132-142.

38. Bondy, C.A., H. Werner, C.T. Roberts, and D. LeRoith. 1990. Cellular pattern of insulin-like growth factor-I (IGF-I) and type I IGF receptor gene expression in early organogenesis: comparison with IGF-II gene expression. Mol. Endocrinol. 4:1386-1398.

39. Liu, J.P., J. Baker, A.S. Perkins, E.J. Robertson, and A. Efstratiadis. 1993. Mice carrying null mutations of the genes encoding insulin-like growth factor I (Igf-1) and type 1 IGF receptor (Igf1r). Cell. 75:59-72.

40. Baker, J., J.P. Liu, E.J. Robertson, and A. Efstratiadis. 1993. Role of insulin-like growth factors in embryonic and postnatal growth. Cell. 75:73-82.

41. Wood, T.L. 1995. Gene-targeting and transgenic approaches to IGF and IGF binding protein function. Am. J. Physiol. 269:E613-622.

42. Quaife, C.J., L.S. Mathews, C.A. Pinkert, R.E. Hammer, R.L. Brinster, and R.D. Palmiter. 1989. Histopathology associated with elevated levels of growth hormone and insulin-like growth factor I in transgenic mice. Endocrinology. 124:40-48.

43. Mathews, L.S., R.E. Hammer, R.L. Brinster, and R.D. Palmiter. 1988. Expression of insulin-like growth factor I in transgenic mice with elevated levels of growth hormone is correlated with growth. Endocrinology. 123:433-437.

44. Mathews, L.S., R.E. Hammer, R.R. Behringer, A.J. D'Ercole, G.I. Bell, R.L. Brinster, and R.D. Palmiter. 1988. Growth enhancement of transgenic mice expressing human insulin-like growth factor I. Endocrinology. 123:28272833.

45. Palmiter, R.D., G. Norstedt, R.E. Gelinas, R.E. Hammer, and R.L. Brinster. 1983. Metallothionein-human GH fusion genes stimulate growth of mice. Science (Wash. DC). 222:809-814.

46. Palmiter, R.D., R.L. Brinster, R.E. Hammer, M.E. Trumbauer, M.G. Rosenfeld, N.C. Birnberg, and R.M. Evans. 1982. Dramatic growth of mice that develop from eggs microinjected with metallothionein-growth hormone fusion genes. Nature (Lond.). 300:611-615.

47. D'Ercole, A.J. 1993. Expression of insulin-like growth factor-I in transgenic mice. Ann. NY Acad. Sci. 692:149-160.

48. Reiss, K., W. Cheng, A. Ferber, J. Kajstura, P. Li, B. Li, G. Olivetti, C.J. Homcy, R. Baserga, and P. Anversa. 1996. Overexpression of insulin-like growth factor-1 in the heart is coupled with myocyte proliferation in transgenic mice. Proc. Natl. Acad. Sci. USA. 93:8630-8635.

49. Coleman, M.E., F. DeMayo, K.C. Yin, H.M. Lee, R. Geske, C. Montgomery, and R.J. Schwartz. 1995. Myogenic vector expression of insulin-like growth factor I stimulates muscle cell differentiation and myofiber hypertrophy in transgenic mice. J. Biol. Chem. 270:12109-12116.

50. Brody, J.R., and G.R. Cunha. 1989. Histologic, morphometric, and immunocytochemical analysis of myometrial development in rats and mice. I Normal development. Am. J. Anat. 186:1-20.

51. Termanini, B., R.V. Nardi, T.M. Finan, I. Parikh, and L.Y. Korman 1990. Insulin-like growth factor I receptors in rabbit gastrointestinal tract. Characterization and autoradiographic localization. Gastroenterology. 99:5160 .

52. Stevenson, K.R., R.S. Gilmour, and D.C. Wathes. 1994. Localization of insulin-like growth factor-I (IGF-I) and -II messenger ribonucleic acid and type 1 IGF receptors in the ovine uterus during the estrous cycle and early pregnancy. Endocrinology. 134:1655-1664.

53. Ulshen, M.H., R.H. Dowling, C.R. Fuller, E.M. Zimmermann, and P.K. Lund. 1993. Enhanced growth of small bowel in transgenic mice overexpressing bovine growth hormone. Gastroenterology. 104:973-980.

54. Ohneda, K., M.H. Ulshen, C.R. Fuller, A.J. D'Ercole, and P.K. Lund 1997. Enhanced growth of small bowel in transgenic mice expressing human insulin-like growth factor I. Gastroenterology. 112:444-454.

55. Lemmey, A.B., F.J. Ballard, A.A. Martin, F.M. Tomas, G.S. Howarth and L.C. Read. 1994. Treatment with IGF-I peptides improves function of the remnant gut following small bowel resection in rats. Growth Factors. 10:243252

56. Kelley, K.M., Y. Oh, S.E. Gargosky, Z. Gucev, T. Matsumoto, V. Hwa, L. Ng, D.M. Simpson, and R.G. Rosenfeld. 1996. Insulin-like growth factorbinding proteins (IGFBPs) and their regulatory dynamics. Int. J. Biochem. Cell Biol. 28:619-637. 